University of Chicago Law School

Chicago Unbound

Journal Articles

Faculty Scholarship

2005

\title{
Endorsement Retires: From Religious Symbols to Anti-Sorting Principles
}

Adam M. Samaha

Follow this and additional works at: https://chicagounbound.uchicago.edu/journal_articles

Part of the Law Commons

\section{Recommended Citation}

Adam Samaha, "Endorsement Retires: From Religious Symbols to Anti-Sorting Principles," 2005 Supreme Court Review 135 (2005).

This Article is brought to you for free and open access by the Faculty Scholarship at Chicago Unbound. It has been accepted for inclusion in Journal Articles by an authorized administrator of Chicago Unbound. For more information, please contact unbound@law.uchicago.edu. 
ADAM M. SAMAHA

\author{
ENDORSEMENT RETIRES: FROM \\ RELIGIOUS SYMBOLS TO ANTI- \\ SORTING PRINCIPLES
}

Our constitutional law respecting religious establishments has nearly nothing to do with the federal government. Putting aside the best reading of constitutional text and constitutional law outside the courts, the central government has little to fear from the Establishment Clause. ${ }^{1}$ In fact, the Supreme Court has almost never invalidated federal action on Establishment Clause grounds. ${ }^{2}$ Maybe this is because national political institutions generate results that are less often troubling to the Court, or because it holds such action to a less demanding standard, or both. Regardless of the best explanation, the law's bite is at the state and local levels.

\footnotetext{
Adam M. Samaha is Assistant Professor, University of Chicago Law School.

Autron's note: Thanks to Christopher Berry, Emily Buss, Mary Anne Case, Mark Chavez, Adam Cox, Jake Gersen, Philip Hamburger, Bernard Harcourt, Saul Levmore, Tracey Meares, Tom Miles, Martha Nussbaum, Michael Stokes Paulsen, Julie Roin, Geof Stone, Lior Strahilevitz, David Strauss, Cass Sunstein, Adrian Vermeule, and Jay Wexler for their comments and suggestions. Shane Davis provided excellent research assistance.

1 "Congress shall make no law respecting an establishment of religion . . .." US Const, Amend I (emphasis added).

${ }^{2}$ The partial exception is Tilton $v$ Richardson, 403 US 672 (1971), which largely upheld a federal construction-grant program that included religious colleges, but which invalidated and severed a provision that would have allowed non-secular use of the funded facilities after twenty years. Aguilar v Felton, 473 US 402 (1985), which invalidated New York's attempt to implement a federal special-education funding program, see id at 404-07, turned on choices made by the locals and was overruled in Agostini v Felton, 521 US 203, 235 (1997).
}

(C) 2006 by The University of Chicago. All rights reserved.

$0-226-36251-5 / 2006 / 2005-0004 \$ 10.00$ 
Knowing this helps account for an overlooked and yet revealing quirk of the endorsement test for Establishment Clause violations: the question is for judges, not juries. ${ }^{3}$ The reason for this allocation of power is not evident from the nature of the test. Roughly speaking, the query is whether a reasonable observer would think that the government sent a message favoring religion over non-religion. ${ }^{4}$ Context matters, including the community setting. ${ }^{5}$ Juries regularly answer questions like this. Negligence cases call for somewhat similar judgment. ${ }^{6}$ Even better, juries may determine whether speech is so offensive to community standards that it qualifies as obscenity. ${ }^{7}$

There is a plausible reason why judges, particularly federal judges, retain control over the endorsement question. Preventing government endorsement of religion can be a shield for minorities within a community against majority orthodoxy. The archetypical endorsement problem is state-orchestrated prayer in public schools. In this scenario, government is proselytizing. It becomes an instrument for propagating mainstream religion, with dissidents either persuaded, submissive, or publicly identified and exposed to ostracism. ${ }^{8}$ Federal courts, which are theoretically more insulated from ordinary political pressure, are then called on to comfort these minorities. But on this account, impaneling a local jury drawn from a fair cross-section of the community would be, to put it politely, counterproductive. The endorsement test was written for and by "outsiders."

The test does more than protect impressionable children, however, and powerful criticisms have been leveled at it. One is that judges manipulate the test to reflect their own tastes for religion, and in a way that provides insufficient warning of what will prompt judicial rebuke. This objection might gain ammunition from the

\footnotetext{
${ }^{3}$ See Lynch v Donnelly, 465 US 668, 694 (1984) (O'Connor, J, concurring); foki v Board of Educ. of Scbuylerville Cent. Sch. Dist., 745 F Supp 823, 829-30 (NDNY 1990).

${ }^{4}$ Or vice versa. See generally Part II.A.

${ }^{5}$ See, e.g., Capitol Sq. Rev. \& Advisory Bd. v Pinette, 515 US 753, 779-80 (1995) (O'Connor, J, concurring) (likening the reasonable observer to the reasonable person in tort law).

${ }^{6}$ See Restatement (Third) of Torts: Liability for Physical Harm $\$ 8$, $\mathrm{cmt} b$ (Proposed Final Draft, 2005).

${ }^{7}$ See, e.g., fenkins $v$ Georgia, 418 US 153, 157 (1974). One might guess that courts do not trust the average non-judge to decide matters touching on religion. But jury participation in employment-discrimination cases is to the contrary. See, e.g., Fobnson v Spencer Press of Maine, Inc., 364 F3d 368, 372-75 (1st Cir 2004).
}

${ }^{8}$ See Abington Sch. Dist. $v$ Schempp, 374 US 203, 224 (1963). 
split decisions in last Term's Ten Commandments cases.' Much doctrine is subject to similar assault, but the endorsement test is especially vulnerable. It seems focused on relatively minor injuries, like offensiveness to adult sensibility, and it is often difficult to predict whether judicial intervention will cause more outrage than it remedies. With the departure of Justice O'Connor-the author and most committed supporter of the endorsement notion-there is a good chance that the test will retire along with her. In fact, because the test is so keyed to judicial perception, a change in personnel almost necessarily changes the rule.

There is another perspective by which a version of the endorsement test might be salvaged-an anti-sorting perspective. Religious messages can be used not only to persuade or ostracize existing community members, they can also signal the community's character to non-members. Depending on the preferences of these outsiders, the message might be either enticing or repugnant. Hurt feelings and inculcation are not the immediate problems, however. The issue is government amplifying a cultural facet of the community and recipients of the message sorting themselves accordingly. ${ }^{10} \mathrm{~A}$ political community's religious character and power structure are not transparent at a glance. Government-approved religious symbols can speak to those matters, thereby helping to achieve a preferred religious composition for the polity. And this is true even if no one changes their religious identity or feels pressure to do so. Proselytizing is not required to prompt sorting. Conceptually the difference is between a sign inside the local schoolhouse reading "Come to Jesus," and a sign at the town border reading, "Come to Corpus Christi, Population 98\% Christian." The first sign clearly proselytizes but both could encourage sorting.

Government messages about religion might therefore be assessed under two principles: anti-proselytism and anti-sorting. These principles can coexist but they are not redundant. Government officials could maximize religious homogeneity across political jurisdictions

\footnotetext{
${ }^{9}$ See McCreary County v ACLU of Ky., 125 S Ct 2722 (2005); Van Orden v Perry, 125 S Ct 2854 (2005); Parts I \& II.A.

${ }^{10}$ Compare Charles M. Tiebout, A Pure Theory of Local Expenditures, $64 \mathrm{~J}$ Pol Econ 416, 418 \& n 12 (1956) (modeling local government competition for mobile citizens). I use the terms "symbols" and "messages" interchangeably.

${ }^{11}$ See Part II.B. For use of signaling theory in support of anti-proselytism rather than anti-sorting principles, see Richard H. McAdams, An Attitudinal Theory of Expressive Law, 79 Or L Rev 339, 383-89 (2000) (bolstering an anti-caste mission).
} 
without overtly proselytizing (e.g., by gerrymandering municipal boundaries), and they might proselytize without prompting interlocal sorting (e.g., by promoting monotheism through federal government mouthpieces). The implications of an anti-sorting principle, moreover, stretch well beyond religious symbols. ${ }^{12}$ First, an anti-sorting perspective deepens our understanding of founding era religious establishments. They might be better characterized as efforts to sort rather than inculcate. Second, the principle can be attached to the nationalizing spirit of the Reconstruction Amendments, along with subsequent judicial and theoretical suggestions that religious faiths should not be divided by political boundaries. Such division risks group polarization across jurisdictions, as well as traditional non-establishment and free-exercise violations within those jurisdictions. Third, an anti-sorting principle recommends a slant in other constitutional doctrine drafted by courts. For example, national standards for religious liberty would be better than local political discretion and the resulting policy variance. In any case, an anti-sorting principle is linked to deep questions about cultural pluralism and government institutions. ${ }^{13}$ Whatever are its imperfections, triviality is not one.

But any anti-sorting principle must meet a new set of challenges. ${ }^{14}$

${ }^{12}$ See Part III.A.-B.

${ }^{13}$ See generally Peter H. Schuck, Diversity in America: Keeping Government at a Safe Distance (2003); Will Kymlicka and Wayne Norman, Citizensbip in Culturally Diverse Societies: Issues, Contexts, Concepts, in Will Kymlicka and Wayne Norman, eds, Citizenship in Diverse Societies 1 (2000). Occasionally these discussions reach religion and the law literature-which has been heavy on political theory and selected precedent, but lighter on history, sociology, and empirical knowledge. See, e.g., Thomas C. Berg, Religion, Race, Segregation, and Districting: Comparing Kiryas foel with Shaw/Miller, 26 Cumb L Rev 365 (1996); Robert M. Cover, The Supreme Court, 1982 Term-Forward: Nomos and Narrative, 97 Harv L Rev 4, 26-33 (1983); Christopher L. Eisgruber, The Constitutional Value of Assimilation, 96 Colum L Rev 87 (1996) (hereafter Eisgruber, Assimilation); Christopher L. Eisgruber, Madison's Wager: Religious Liberty in the Constitutional Order, $89 \mathrm{Nw}$ U L Rev 347 (1995) (hereafter Eisgruber, Madison); Judith Lynn Failer, The Draw and Drawbacks of Religious Enclaves in a Constitutional Democracy: Hasidic Public Schools in Kiryas 7oel, 72 Ind L J 383 (1997); Abner S. Greene, Kiryas Foel and Two Mistakes About Equality, 96 Colum L Rev 1 (1996); Sanford Levinson, On Political Boundary Lines, Multiculturalism, and the Liberal State, 72 Ind L J 403 (1997); Sanford Levinson, Some Reflections on Multiculturalism, "Equal Concern and Respect," and the Establisbment Clause of the First Amendment, 27 U Richmond L Rev 989 (1993); Ira C. Lupu, Uncovering the Village of Kiryas Foel, 96 Colum L Rev 104 (1996); see also Schuck, Diversity in America, ch 7; Richard C. Schrager, The Role of the Local in the Doctrine and Discourse of Religious Liberty, 117 Harv L Rev 1810 (2004) (arguing that local-government action should be another factor in Establishment Clause doctrine); Steven H. Shiffrin, The Pluralistic Foundations of the Religion Clauses, 90 Cornell L Rev 9, 89-90 (2004) (discussing religious instruction).

${ }^{14}$ See Part III.B.-C. 
One task is practical. The principle must be elaborated in a way that is concrete, coherent, and administrable, especially if courts will be involved. Options range from modest versions that prohibit government action only if it purposely pushes citizens to separate along political boundaries, to more assertive versions that inhibit less intentional facilitation of religious sorting, or that demand affirmative government action to achieve religious "diversity." A possible legal analogue is racial segregation, but the constitutional arguments play out differently with respect to religion. A related problem for any anti-sorting principle is normative. A mixture of religious views within each political jurisdiction is a contentious mission. Local homogeneity can be a virtue, as Charles Tiebout and his followers have tried to demonstrate. Religious symbols could be roughly accurate representations of community character and therefore helpful warnings or welcome signs. As well, much about the sociology of religious sorting in America is unknown.

In some ways, the endorsement test is caught between a marginal goal that produces as much animosity as reconciliation, and a monumental goal that is encumbered with normative, positive, and practical difficulties. Not every relevant question can be answered here; and I will conclude that current knowledge supports only a modest anti-sorting principle that is judicially enforceable. ${ }^{15}$ This is nevertheless an important supplement to present understandings of constitutionally problematic religious establishments. Without preempting the field, an anti-sorting perspective exposes unrecognized features of old and new controversies, it fits with judicial skepticism about local treatment of religion, and it gives reason to pay attention to symbolic battles. ${ }^{16}$

\section{Decalogues}

Last Term, the Supreme Court decided two cases involving Ten Commandments renderings. In a practical sense, however, a third display was under consideration: the Court's own frieze of lawgivers. ${ }^{17}$ One of them is located in the courtroom, above and to

\footnotetext{
${ }^{15}$ See text accompanying notes 199-204, 252.

${ }^{16}$ Religious sorting in state and local governments is the concern. I set aside religiously homogenous electoral districts, which raise distinct issues. See Part III.B.1. Nor do I discuss sorting across national boundaries.

${ }^{17}$ See Office of the Curator, Supreme Court of the United States, Information Sbeet: Courtroom Friezes: Nortb and South Walls (2000), online at http://www.supremecourtus.gov/ about/north\&southwalls.pdf.
} 
the left of the bench from the Justices' perspective. In this rendering, Moses is holding two tablets representing the Commandments. But only the second half of the Decalogue is visible at all; that portion is written in Hebrew and mostly obscured by Moses's body. He is squeezed between Hammurabi and Solomon, not far from Menes of Egypt and Lycurgus of Sparta-thus set within a line of a dozen other figures, like a Metro car full of lawgivers at rush hour. Whatever one's aesthetic tastes, the frieze is an impressive enough achievement as a matter of craft, which should be no surprise. Its specific content and shape were delegated to a skilled architectural sculptor who was responsible for other pieces of national culture, like the design of the dime. ${ }^{18}$

Uncertainty surrounded the outcome of the two docketed cases, but the Court's own use of religion-connected imagery was not at risk. The aesthetic character of Washington, D.C., is a safe harbor. Even Justice Brennan's dissent in Lynch $v$ Donnelly ${ }^{19}$ - which opposed seasonal municipal displays of a Nativity scene accompanied by less religious symbols-made an effort to preserve "In God We Trust" on the national coinage and "under God" in the Pledge of Allegiance. ${ }^{20}$ When a challenge to voluntary recitation of the Pledge reached the Court, a majority dodged the merits on a novel standing theory and the rest proclaimed their support for such nationalistic references to monotheism. ${ }^{21}$ These messages are not inclusive enough to reach several prominent religions in the United States, and calling them "nondenominational" is a bit of unearned selfcongratulation. If there were 20 million Hindus and 20 million Buddhists in this country the judiciary and Congress might think differently. ${ }^{22}$ But maybe current practice is close enough for con-

\footnotetext{
${ }^{18}$ See Sydney P. Noe, The Medallic Work of A. A. Weinman, 7 Numismatic Notes \& Monographs 1, 8 (1921).

${ }^{19} 465$ US 668 (1984).

${ }^{20} \mathrm{Id}$ at 716-17 (Brennan, J, dissenting) (expressing uncertainty but offering arguments).

${ }^{21}$ See Elk Grove Unified Sch. Dist. v Newdow, 124 S Ct 2301, 2305 (2004); id at 2316-20 (Rehnquist, CJ, concurring) (reaching the merits); id at 2323-27 (O'Connor, J, concurring) (same, listing factors for a ceremonial-deism safe harbor); id at 2327, 2330 (Thomas, J, concurring) (same, relying on a modest anti-coercion rule and resistance to incorporation).

${ }^{22}$ See Ariela Keysar, Barry A. Kosmin, and Egon Mayer, American Religious Identification Survey 6, 13 (2001) (hereafter ARIS Survey) (reporting results of a national telephone survey of 50,000 adults and estimating that, in 2001, there were 1,182,000 self-identified Buddhists and 766,000 Hindus-numbers more than double the results in a similar 1990 study); see also Roger Finke and Rodney Stark, The Churching of America, 1776-2005: Winners and Losers in Our Religious Economy 241 (2d ed 2005) (reporting larger numbers).
} 
stitutional work, and in any event the ceremonial deism that Washington ordinarily produces is protected from judicial interference.

The two cases on the docket presented questions about state and local displays. The state-sanctioned display was, almost literally, a fifty-year-old version of the Commandments. Among Englishspeaking adherents to the Hebrew Bible, there is no "the" Ten Commandments. Different Bibles differently translate the Book of Exodus from Hebrew to English. Some of the differences are organizational or structural (like numbering and therefore grouping); others are textual. One potentially important choice is between an injunction against "kill[ing]" or "murder[ing]." ${ }^{23}$ Those who created the monument at issue in Van Orden $v$ Perry ${ }^{24}$ understood this. Ultimately working with a private civic association, a committee representing Protestants, Catholics, and Jews selected the wording for a Ten Commandments monument. ${ }^{25}$ It is not a transcription from any Bible of which I am aware. The structure looks Lutheran while the text seems to be an excerpt from the Protestant King James version. ${ }^{26}$ Perhaps hundreds of such monuments were distributed throughout the country, at least ostensibly in an effort to reduce juvenile delinquency. ${ }^{27}$ One six-foot-high monument ended up on the capitol grounds in Austin, Texas:

\section{AM the LORD thy God.}

Thou shalt have no other gods before me.

Thou shalt not make to thyself any graven images.

Thou shalt not take the Name of the Lord thy God in vain.

Remember the Sabbath day, to keep it holy.

Honor thy father and thy mother, that thy days may be long upon the land which the Lord thy God giveth thee.

Thou shalt not kill.

Thou shalt not commit adultery.

Thou shalt not steal.

${ }^{23}$ Compare The Holy Bible: Autborized King 7ames Version 72 (World Publishing Co., 1972) ("Thou shalt not kill.") and The Holy Bible: Confraternity-Douay Version 98 (Catholic Book Publishing Co., 1961) ("You shall not kill."), with Tanakb: The Holy Scriptures 116 (Jewish Publication Soc., 1985) ("You shall not murder.") and The Access Bible: New Revised Standard Version 96 (Oxford, 1999) (same); id at $96 \mathrm{n} \mathrm{c} \mathrm{("Or} \mathrm{kill").} \mathrm{An} \mathrm{accessible} \mathrm{discussion}$ that emphasizes the textual and possible substantive differences is Paul Finkelman, The Ten Commandments on the Courthouse Lawn and Elsewbere, 73 Fordham L Rev 1477 (2005).

${ }^{24} 125$ S Cr 2854 (2005).

${ }^{25}$ See Books $v$ City of Elkbart, 235 F3d 292, 294 (7th Cir 2000).

${ }^{26}$ See Finkelman, 73 Fordham L Rev at 1492 (cited in note 23).

${ }^{27}$ See Van Orden, $125 \mathrm{~S} \mathrm{Ct}$ at 2878 (Stevens, J, dissenting). 
Thou shalt not bear false witness against thy neighbor.

Thou shalt not covet thy neighbor's house.

Thou shalt not covet thy neighbor's wife, nor his manservant, nor his maidservant, nor his cattle, nor anything that is thy neighbor's.

PRESENTED TO THE PEOPLE AND YOUTH OF TEXAS BY THE FRATERNAL ORDER OF EAGLES OF TEXAS $1961^{28}$

If one takes the capitol grounds as the frame, the Eagle's monument is not alone. It was placed among several others dedicated to historical events and good deeds of factions within the state. ${ }^{29}$ In a sense, the Texas display is more reflective of private social movements, but its surroundings have an ecumenical quality similar to the Court's frieze.

The county-level display in McCreary County $v$ ACLU of Ken$t^{t u c k} y^{30}$ was the least cosmopolitan of the three. The Ten Commandments element consisted of a framed sheet of paper. It was surrounded by other documents, such as the Declaration of Independence, which have at best a tangential historical relationship to the Decalogue. County officials chose to transcribe in more detail the King James version from its Book of Exodus and, unlike the Texas monument, the document was so labeled. ${ }^{31}$ As such the remainder of the text and structure was similar to the Eagles's choices forty years earlier yet distinct. ${ }^{32}$ The warning about graven images was reprinted in full, closing with a penalty clause: "for I the LORD thy God am a jealous God, visiting the iniquity of the fathers upon the children unto the third and fourth generation of them that hate me." Taking the Lord's name in vain was supplemented with a second caution: "for the LORD will not hold him guiltless that taketh his name in vain." And the final clauses on coveting are grouped together, altering the implied numbering of the Commandments. ${ }^{33}$ No outside organization appears to have motivated the display, although a county resolution indicates officials wanted

\footnotetext{
${ }^{28}$ See id at $2873-74,2891$.

${ }^{29}$ See id at 2858 (plurality opinion of Rehnquist, CJ).

${ }^{30} 125$ S Ct 2722 (2005). In the text, I am referring to the third and final version.

${ }^{31}$ See id at 2730 .

${ }^{32}$ See id at 2730-31; Letter from Nancy Rankin, ACLU of Ky, to Adam Samaha, University of Chicago Law School 2 (Oct 24, 2005) (on file with the author) (reproducing the display).

${ }^{33}$ McCreary's document also referred to coveting "ox" and "ass" rather than "cattle."
} 
to show support for Roy Moore, ${ }^{34}$ and the county was working around federal court supervision. ${ }^{35}$ Residents took up a collection for litigation expenses. ${ }^{36}$ So the local version was more home-grown, sectarian, and contemporary than its state and national counterparts.

Perhaps the results should have been predicted. The Court permitted the state's display and prohibited the county's. The former was closer to the frieze and the Pledge. Although the Court was divided and relied on the county's alleged purpose of endorsing religion, ${ }^{37}$ the differences in content among the displays are notable. Not every locality would produce a display like McCreary's, of course. One would expect Chicago's population and politics to differ from those of Kentucky coal country. The point is that decentralizing religious symbolism produces messages often different from comparable national efforts, and with meaningful variance among localities. Judged by self-identification, no religion exceeds 25 percent of the national population; ${ }^{38}$ but localizing decisions changes the mixture of religious values.

\section{Missions}

The question is whether anyone, especially courts, should care about the way government is decorated. The textual hooks are of course the First and Fourteenth Amendments. ${ }^{39}$ But conventional sources of interpretation leave important questions open. So courts select particular problems for attention, which begs the question about religious symbolism cases. Nobody is losing the right to vote, or speak, or receive tangible government benefits; nobody is formally compelled to attend or not attend religious ceremonies; nobody is taxed to pay for substantial material benefits to religious causes. And yet Supreme Court majorities have supported an en-

\footnotetext{
${ }^{34}$ See $M c$ Creary, $125 \mathrm{~S} \mathrm{Ct}$ at 2729 . Moore ultimately lost his well-publicized effort to maintain a Ten Commandments monument at the Alabama State Judicial Building. See, e.g., Glassroth v Moore, 335 F3d 1282 (11th Cir), cert denied, 540 US 1000 (2003).

${ }^{35}$ See, e.g., ACLU of Ky. v Pulaski County, 96 F Supp 2d 691, 702 (ED Ky 2000).

${ }^{36}$ See Letter from Jimmie W. Greene, McCreary County, to Adam Samaha, University of Chicago Law School 1 (Oct 21, 2005) (on file with the author) (recollecting that little money was collected in the defense fund and that the money was spent on radio and newspaper advertisements).

${ }^{37}$ See text accompanying note 74 .

${ }^{38}$ See ARIS Survey at $12-13$ (cited in note 22).

${ }^{39}$ See Everson v Board of Educ. of Ewing Township, 330 US 1, 14-15 (1947).
} 
dorsement test that sometimes prohibits government affiliation with religious messages.

This section offers two possible justifications. The first is conventional wisdom: courts are enforcing a principle against state proselytizing, which attends to direct psychic and cultural impact within a static community membership. On its own, that principle probably cannot sustain the endorsement test in its current form. The second justification has not been noticed but its objective is far from trivial. It can be expressed as an anti-sorting principle, which is generally opposed to religiously monolithic localities. As applied to religious symbols, the concern is people judging the religious character of a community and then sorting themselves accordingly. Unlike anti-proselytism, an anti-sorting principle may apply even if nobody is offended, convinced, or ostracized.

\section{A. ORTHODOXY: GOVERNMENT PROSELYTIZING}

In 1984, Justice O'Connor suggested a refashioning of Establishment Clause doctrine around the idea of non-endorsement. Attempting to capture the essence of the clause, she asserted that government must not act with the purpose or effect of endorsing religion over non-religion, or one religion over another. ${ }^{40}$ More generally, religion should not be relevant to anyone's "standing in the political community." "In" has unappreciated significance. It indicates that the test targets localities that treat some of their current members as if they were outsiders. Prohibited endorsement informs religious nonadherents that they are "outsiders, not full members of the political community," and it conveys to adherents that they are "insiders, favored members of the political community." 42

The endorsement test became popular with some, but it failed to unify the field. Justices most skeptical of government benefits flowing to religion embraced the test, sometimes forging major-

\footnotetext{
${ }^{40}$ See Lynch v Donnelly, 465 US 668, 688, 690 (1984) (O'Connor, J, concurring) (stating that government may not disapprove of religion, either); cf. Lemon $v$ Kurtzman, 403 US $602,612-13$ (1970) (referring to secular purpose, religious effect, and excessive entanglement).

${ }^{41}$ Lynch, 465 US at 687 (O'Connor, J, concurring).

${ }^{42}$ Id at 688 ("Disapproval sends the opposite message.").
} 
ities. $^{43}$ In addition, some commentators were excited. A strong form of the test fit with certain "neutrality" theories of the religion clauses, ${ }^{44}$ and some scholars saw an opportunity to merge race issues under the Equal Protection Clause. ${ }^{45}$ But the test never fulfilled these hopes. Endorsement did not become the sole touchstone for Establishment Clause claims; the Supreme Court did not adopt neutrality toward religion as a guiding principle in any strong form; ${ }^{46}$ and unsuccessful challenges to displays of the Confederate battle flag $^{47}$ suggested the idea of non-endorsement might be an orphan in constitutional law.

Moreover, the endorsement test prompts strange questions. It might make a difference whether the government mails checks to religious organizations according to the number of people they serve, or instead sends the checks to individuals who will then sign them over to those same organizations. ${ }^{48}$ Such inquiries seem unhelpful at best. It might be important that individual beneficiaries choose whether their religious service providers receive state funding, but that does not depend on the immediate recipient of the funds. And it is hard to see the good use for such perception-

\footnotetext{
${ }^{43}$ See, e.g., Santa Fe Indep. Sch. Dist. $v$ Doe, 530 US 290, 308 (2000) (addressing a system facilitating prayer before high school football games); County of Allegheny $v$ ACLU Greater Pittsburgb Ch., 492 US 573, 593 (1989) (addressing a Nativity scene in a county courthouse).

${ }^{44}$ See, e.g., Douglas Laycock, Theology Scholarships, the Pledge of Allegiance, and Religious Liberty: Avoiding the Extremes but Missing the Liberty, 118 Harv L Rev 155, 177, 223 (2004); Arnold H. Loewy, Retbinking Government Neutrality Toward Religion Under the Establishment Clause: The Untapped Potential of Justice O'Connor's Thought, 64 NC L Rev 1049, 1055-59, 1069 (1986).

${ }^{45}$ See Kenneth L. Karst, The First Amendment, the Politics of Religion and the Symbols of Government, 27 Harv CR-CL L Rev 503, 512-25 (1992).

${ }^{46}$ See, e.g., Zelman v Simmons-Harris, 536 US 639 (2002); Mitchell v Helms, 530 US 793 (2000). In fact, Justice O'Connor initially promoted her test as a way to preserve some state action benefiting religion, such as exemptions from secular regulation and mere "acknowledgment" of American religious heritage. See Lynch, 465 US at 691-93 (O'Connor, J, concurring).

${ }^{47}$ See Coleman v Miller, 117 F3d 527, 530-31 (11th Cir 1997) (per curiam), cert denied, 523 US 1011 (1998); NAACP v Hunt, 891 F2d 1555, 1565 (11th Cir 1990) ("The federal judiciary is not empowered to make decisions based on social sensitivity."); Mississippi Div. of United Sons of Confederate Veterans $v$ Mississippi State Conf. of NAACP Branches, 774 So2d 388, 389-90 (Miss 2000); Daniels v Harrison County Bd. of Supervisors, 722 So2d 136, 137 (Miss 1998); cf. Briggs v Mississippi, 331 F3d 499, 502, 508 (5th Cir 2003) (rejecting an Establishment Clause attack on the St. Andrews-cross-like element of the Confederate battle flag, which is incorporated into the Mississippi state flag), cert denied, 540 US 1108 (2004).

${ }^{48}$ See Mitcbell, 530 US at 842-43 (O'Connor, J, concurring) (referring to public perceptions).
} 
centered questions in adjudicating emerging controversies, like exemptions from conditions on government subsidies for religious recipients. Before she retired, Justice O'Connor herself openly doubted that the Establishment Clause could be sensibly implemented in one test. ${ }^{49}$

Non-endorsement is now restricted in scope but it remains vital in the government-speech context. ${ }^{50}$ One reason is heritage. It is an extension of the school prayer cases decided in the $1960 \mathrm{~s}^{51}$ They dealt with government officials delivering religious messages to children in public schools, which were provided at no extra charge to parents who were legally obligated to educate their children somewhere. The exact effect of these religious exercises is not really known. Some children surely accepted the content already, or were deaf to it; others might have been inculcated, or identified themselves as dissenters by not participating. ${ }^{52}$ In any case, the Court held government proselytizing intolerable in this setting-even if students were formally permitted to opt out. ${ }^{53}$ Although the Court sought to prohibit more than conventional coercion, ${ }^{54}$ there was unmistakable attention to circumstances of persuasion. The gist of the endorsement test in its present form is not far removed from anti-proselytism. It is supposed to shield community members from government-backed messages that make them feel like outsiders. ${ }^{55}$

\footnotetext{
${ }^{49}$ See Board of Educ. of Kiryas 7oel Vill. Sch. Dist. $v$ Grumet, 512 US 722, 718-21 (1994) (O'Connor, J, concurring).

${ }^{50}$ See id at 720 (suggesting this application).

${ }^{51}$ The word was even used. See Engel v Vitale, 370 US 421, 436 (1962) (acknowledging that the "governmental endorsement" of a prayer might seem insignificant); Abington Scb. Dist. $v$ Schempp, 374 US 203, 257 n 23 (1963) (Brennan, J, concurring), quoting Letter of Dec 7, 1871, to Rev D. McAlister, in Charles Bradley, ed, Miscellaneous Writings of the Late Hon. Fosepb P. Bradley 357-58 (1901) ("The Constitution was evidently framed and adopted . . . to avoid all appearance even of a State religion, or a State endorsement of any particular creed or religious sect."); see also, e.g., Lowe v City of Eugene, $463 \mathrm{P} 2 \mathrm{~d} 360$, 363 (Or 1969) (addressing a publicly displayed religious symbol), cert denied, 397 US $1042(1970)$.

${ }^{52}$ See Schempp, 374 US at 205-12 (noting opt-out rights and describing trial testimony).

${ }^{53}$ Contrast West Va. Bd. of Educ. v Barnette, 319 US 624, 642 (1943), which thundered, "no official, high or petty, can prescribe what shall be orthodox in politics, nationalism, religion, or other matters of opinion," yet allowed flag-salute ceremonies to go on with formal opt-out rights.

${ }^{54}$ See Schempp, 374 US at 223; Engel, 370 US at 431; accord Lee $v$ Weisman, 505 US 577,587 (1992).

${ }^{55}$ See Wallace v Faffree, 472 US 38, 70 (1985) (O'Connor, J, concurring) (worrying about pressure on non-adherents and quoting Engel, 370 US at 431).
} 
Criticism of the test has not been so much about its origins as its alleged extravagance and self-reference. ${ }^{56}$ Judicial proponents of the test seem fixated on stand-alone psychological injuries that might not be judicially cognizable in other fields of constitutional law. ${ }^{57}$ There is a long distance between feelings of alienation produced by government symbols and those produced by more severe manifestations of second-class citizenship, such as the inability to receive cash benefits, to vote, or to hold office. This is not to dismiss emotional injury as beneath concern. ${ }^{58}$ The doctrine, moreover, might be defended as prophylactic. Perhaps fearing manipulation of religious culture by the state, courts intervene at the threat's outer boundaries. But the intervention is not cost-free. Soothing secular and religious minorities in this way can incite the hostility of local majorities. Even if locals are not apoplectic about having to modify a religious display (the stakes might be judged equally low for supporters of these messages), national interest groups are sometimes happy to bear litigation costs. In fact, these groups might gain by losing on the merits. ${ }^{59}$ And at least equally important problems - public symbols associated with racism-were left unaddressed..$^{60}$

Furthermore, a test that is too restrictive will prevent real gains

\footnotetext{
${ }^{56}$ Especially helpful critiques are Jesse $\mathrm{H}$. Choper, The Endorsement Test: Its Status and Desirability, 18 J L \& Pol 499 (2002), and Steven D. Smith, Symbols, Perceptions, and Doctrinal Illusions: Establishment Neutrality and the "No Endorsement" Test, 86 Mich L Rev 266 (1987).

${ }^{57}$ See Allen v Wright, 468 US 737, 755 (1984) (recognizing racial stigma as a cognizable injury if the litigant was personally denied equal treatment); cf. United States $v$ Hays, 515 US 737, 744-45 (1995) (denying standing to non-residents of a congressional district allegedly gerrymandered by race, yet indicating residents have standing because of the risks of representational harm).

${ }^{58}$ Converting emotional harm into a damages figure is challenging but this does not mean there is no harm. Nor are religious symbolism cases get-rich-quick schemes. Damages are rarely at issue.

${ }^{59}$ Compare Alan Cooperman, Cbristian Groups Plan More Monuments, Washington Post (June 28, 2005) A6 (reporting that both sides "said the displays are now the frontline of a proxy war, standing in for the bigger issue of the place of religion in public life").

${ }^{60}$ Compare Jesse H. Choper, Securing Religious Liberty: Principles for Fudicial Interpretation of the Religion Clauses 101-02 (1996) (arguing that racially stigmatizing messages are the greater concern). But cf. Virginia v Black, 538 US 343, 361-63 (2003) (permitring states to punish cross burning with intent to intimidate, given certain safeguards). For a nuanced account of Confederate monuments, see Sanford Levinson, Written in Stone: Public Monuments in Changing Societies 76-77, 104-10 (1998) (indicating some government use of religious symbols should be judicially policed, but not existing Confederate battle flags). For other views on flags, see Bennett Capers, Flags, 48 Howard L J 121 (2004), and James Foreman, Jr., Note, Driving Dixie Down: Removing the Confederate Flag from Southern State Capitols, 101 Yale L J 505 (1991).
} 
toward secular goals. Cobb County, Georgia's, stickers for biology textbooks ("Evolution is a theory, not a fact . . ..") were crudely phrased, but they were apparently bundled with the decision to make instruction on evolution mandatory instead of optional. ${ }^{61}$ If religious opposition to such instruction was widespread and if the participants were acting in good faith, it might have made sense to exchange a sign of respect for a broader education in mainstream science. Probably no other scientific theory is so accepted within the discipline and so openly doubted in public opinion. ${ }^{62}$ Compromise on educational method is a delicate matter, but a judicial bar on negotiation might hinder a comprehensive science curriculum. ${ }^{63}$

Then there are issues of vagueness and perspective. Constitutional violations based on religious offense to any one observer would multiply beyond control, so a "reasonable" observer's perspective was adopted. ${ }^{64}$ This led to debate about the characteristics of the construct. ${ }^{65}$ Perhaps not surprisingly, Justice O'Connor's reasonable observer came to look more and more like the judge who was operating the test: striving for some kind of objectivity, familiar with the history and context of the state action at issue, perhaps misperceiving the government's intended message. ${ }^{66}$

\footnotetext{
${ }^{61}$ See Selman v Cobb County Sch. Dist., 390 F Supp 2d 1286, 1289-97, 1313 (ND Ga 2005) (enjoining use of the stickers). The full text of the sticker is, "This textbook contains material on evolution[.] Evolution is a theory, not a fact, regarding the origin of living things[.] This material should be approached with an open mind, studied carefully, and critically considered." Id at * 5 . Evolution is a theory (regarding species diversity) - but so is gravity, and thus the issue is the district's decision to single out evolution in this way.

${ }^{62}$ See, e.g., Lisa Anderson, Museums Take Up Evolution Cballenge, Chi Trib (Oct 16, 2005) (reporting results of a 2005 Gallup Poll in which 53 percent of respondents indicated a belief that "God created humans in their present form exactly the way the Bible describes it," 31 percent indicated that God guided a process whereby humans evolved over millions of years from other life forms, and 12 percent indicated that humans evolved but God played no part in the process).

${ }^{63}$ See also Tracey Meares and Kelsi Brown Corkran, When 2 or 3 Come Togetber, University of Chicago Public Law Working Paper No. 107 (Oct 2005) (discussing police use of a religious message to help organize church leaders).

${ }^{64}$ See, e.g., McCreary County v ACLU of Ky., 125 S Ct 2722, 2737 (2005); Elk Grove Unified Sch. Dist. v Newdow, 124 S Ct 2301, 2321 (2004) (O'Connor, J, concurring); see also Santa Fe Indep. Sch. Dist. $v$ Doe, 530 US 290, 308 (2000) (assuming the perspective of an objective high school student at a football game).

${ }^{65}$ Compare Capitol Sq. Rev. \& Advisory Bd. v Pinette, 515 US 753, 780-82 (1995) (O'Connor, J, concurring) (assuming more knowledge), with id at 807-08 \& n 14 (Stevens, $\mathrm{J}$, dissenting) (assuming less knowledge).

${ }^{66}$ See id at 776-77, 780-82 (O'Connor, J, concurring) (intimating that the reasonable observer can be reasonably confused); Wallace $v$ faffree, 472 US 38, 70 (1985) (O'Connor, $\mathrm{J}$, concurring).
} 
Some of these problems are reparable matters of detail, but the endorsement test is problematic even for those committed to an anti-proselytism principle.

All of which leaves endorsement in a precarious state. In last Term's cases, the fissures were obvious. Although the Court is essentially unanimous on some kind of anti-proselytism principle, ${ }^{67}$ several Justices oppose the non-endorsement concept as too stringent, while the test's adherents disagree on its precise content. Thus the Texas monument was left standing by a plurality basically unconcerned with "passive" and non-"coercive" displays of monotheism, ${ }^{68}$ plus Justice Breyer, whose pragmatism counseled against sending forklifts to remove this and perhaps hundreds of other decades-old monuments. ${ }^{69}$ His opinion was overtly antidoctrine, claiming to find no guidance in tests and instead pointing to vague principles and a bundle of facts. ${ }^{70}$ For example, taking the capitol grounds as the denominator and considering the civic and ecumenical features of the donor, one might see a reflection of several influential components of state heritage without an obtrusive effort to promote religious faith per se. The case did involve government's connection to religious symbols, but not a very effective form of proselytism.

McCreary County's conduct was judged differently. Justice Breyer seemed to revert to a presumption against government attachment to religious content, ${ }^{71}$ and he must have guessed that in this instance judicial intervention was worth the resulting local friction. A municipality was changing the aesthetic status quo,

${ }^{67}$ Justice Kennedy has written that the government should not proselytize and that a Latin cross on the top of city hall would be unconstitutional. See County of Allegheny $v$ ACLU Greater Pittsburgb Ch., 492 US 573, 661 (1989) (Kennedy, J, concurring in part and dissenting in part). Justice Scalia's dissent in McCreary County suggests that government cannot take official positions on live controversies over religious doctrine, see $125 \mathrm{~S} \mathrm{Ct}$ at $2762 \mathrm{n} \mathrm{12-which} \mathrm{presumably} \mathrm{would} \mathrm{foreclose} \mathrm{a} \mathrm{national} \mathrm{Book} \mathrm{of} \mathrm{Common} \mathrm{Prayer} \mathrm{or}$ an official translation of the Hebrew Bible. Justice Thomas is a partial exception because he would not apply Establishment Clause norms to the states, see, e.g., Newdow, $124 \mathrm{~S}$ $\mathrm{Ct}$ at 2328 (Thomas, J, concurring), but he would so apply anti-coercion norms from the Free Exercise Clause, see id at 2330,2333 n 5.

${ }^{68}$ See Van Orden, $125 \mathrm{~S} \mathrm{Ct}$ at 2861 (plurality opinion of Rehnquist, CJ).

${ }^{69}$ Compare id at 2870 (Breyer, J, concurring) (stressing the absence of strife surrounding the monument until this suit, and lack of evidence that the placidity was due to oppression).

${ }^{70}$ See id at 2871.

${ }^{71} \mathrm{He}$ joined Justice Souter's majority opinion. To confirm a strong preference for only secular government symbols, we would need to know whether Justice Breyer would invalidate a municipal choice to remove a religious symbol from government property despite risks of strife. 
partial to the King James Decalogue, and associating itself with Roy Moore's challenge to federal authority. A majority was achieved with three other Justices who strongly prefer government abstention from religious messages, and Justice O'Connor, who connected the issue to freedom of conscience ${ }^{72}$ and therefore proselytism. Distinguishing the county's final display from the Texas version was tricky, though. Its Decalogue was joined with several documents lacking religious content. ${ }^{73}$ So the majority concentrated on the legislative and litigation history, condemning what it took to be the county's purpose of highlighting religious messages. ${ }^{74}$ This strategy is telling, and not only because this purpose suggests a future threat of proselytizing. It indicates concern with how municipalities operate, not just how they look.

But appearances do matter for endorsement purposes and many observers cannot identify a sufficiently important mission for the test. It is a step removed from government proselytizing. It comes with the risk of populist backlash. And it seems to incorporate a self-referential and D.C.-centric religious aesthetic that is foreign to many localities.

\section{B. REFORMULATION: RELIGIOUS SORTING}

There might be another way to justify something like a nonendorsement rule, but it requires a departure from the anti-proselytism perspective. Instead, an anti-sorting principle would animate judicial intervention and oppose the coincidence of political and religious boundaries. There is a connection between antisorting and anti-proselytism principles, which will be apparent in the discussion below. For instance, a public school district's decision to promote a literal reading of the Book of Genesis as contradicting and superior to any scientific theory of evolution would be a basis for sorting into and out of that jurisdiction. Antiproselytism and anti-sorting have different legal implications, however, and they require different justifications. ${ }^{75}$ But for all its problems - and they are serious - an anti-sorting principle extends

\footnotetext{
${ }^{72}$ See McCreary County, $125 \mathrm{~S} \mathrm{Ct}$ at 2746 (O'Connor, J, concurring).

${ }^{73} \mathrm{See}$ id at 2731 (opinion of the Court).

${ }^{74}$ See id at 2737-41 (noting one display that posted a version of the Decalogue essentially alone and a second that added other texts but emphasized their religious content).

${ }^{75}$ See Part III.A.-B.
} 
the mission of non-endorsement beyond prevention of offense.

To get the gist of how interlocal sorting might work, Charles Tiebout's well-known model is a good place to start. Different people have different preferences for government services and taxation, as well as matters of lifestyle. If we permit state and local governments to offer different policy packages, and if we permit mobile citizens to select among these governments, then (given some additional assumptions) government offerings will better match preset citizen preferences and implementation of these policies should be easier. Voting and other forms of voice might be far less significant than the dynamic created by citizens with an exit option. In fact, a big selling point for the model was that, through migration, citizen preferences for public goods would be credibly revealed to government officials. ${ }^{76}$

But the model then adds a strong assumption about the knowledge of citizens. It assumes consumer-voters have perfect information about the available policy packages. ${ }^{77}$ Certain municipal features, like property taxes or road conditions, are easy to ascertain. Others are not. How people interact, their preferences beyond policy, the set of informal associations, the social hierarchy, the political power structure, and other elements of "community character" are difficult to grasp at a glance-at least in the absence of an effort by insiders to signal outsiders. Whether deciding on where to reside, recreate, retire, or work, outsiders will often care about these intangible features of a community.

A community's religious character may fall into the second category. Unlike race ${ }^{78}$ one's religion is not necessarily a visible feature. Looking at people is a low-probability tool for an outsider seeking knowledge about neighborhood religion. And reliable demographic data on religion are surprisingly difficult to obtain. Again unlike race, for which statistics are available decennially at the micro-levels of census tract and block, ${ }^{79}$ religious-affiliation data are no longer collected by the federal government. ${ }^{80}$ County-

\footnotetext{
${ }^{76}$ See Tiebout, $64 \mathrm{~J}$ Pol Econ at 418-19 (cited in note 10).

7 See id at 419 (assumption 2 regarding "full knowledge").

${ }^{78}$ In its socially defined sense. See Pierre L. Van den Berghe, Race and Racism: A Comparative Perspective 9 (1967) (incorporating physical criteria into the definition).

${ }^{79}$ The data are available at http://www.census.gov. For census purposes, "race" is selfreported and so responses will not necessarily track social definitions of race.

${ }^{80}$ Between 1850 and 1936, the Census Bureau collected membership data from religious organizations. See 1 U.S. Bureau of the Census, Historical Statistics of the United States:
} 
level data are assembled by private parties, ${ }^{81}$ but even these numbers are not entirely dependable. Because the survey depends on reporting by participating religious organizations, sometimes total reported religious membership will exceed the best estimate of the total population; on other occasions the "unclaimed" population is implausibly high. ${ }^{82}$ Thus we can conclude with reasonable confidence-and from any personal computer with Internet access-that in the year 2000 there were approximately 17,080 McCreary County residents, of whom 108 identified themselves as African American or black, nearly all of whom lived in the Pine Knot area. But the fraction of the county's 2000 population unclaimed by any participating religious organization is 76 percent ${ }^{83}$ This number cannot say anything meaningful about religious life and power in the county, given a local government that defended multiple Ten Commandments displays against costly ACLUbacked litigation. ${ }^{84}$

Even if demographic data on religion were perfect, sorting would still be more difficult than a Tiebout enthusiast would prefer. Aside from speech restrictions on real estate agents inspired by the Fair Housing Act, ${ }^{85}$ there is the question of local political power. This will never be transparent from demographic information. More is needed, and a government's chosen symbols can

Colonial Times to 1970 at 389 (1975); Finke and Stark, The Cburching of America at 16, 295 n 4 (cited in note 22). Although no religion data were collected by the Bureau after the 1940 s, in 1976 Congress prohibited the Bureau from making religion-related questions mandatory. See Pub L No 94-521, $₫ 13(3)$, 90 Stat 2459 (1976) (codified at 13 USC $\$$ $221(\mathrm{c}))$.

${ }^{81}$ See Religious Congregations and Membership in the United States 2000: An Enumeration by Region, State and County Based on Data Reported for 149 Religious Bodies (Dale E. Jones et al, eds, 2001) (hereafter ASARB Data).

${ }^{82}$ See generally id at $\mathrm{xv}-\mathrm{xvv}$ (listing 39 counties where claimed adherents exceeded census population figures and offering possible explanations); id at xiii-xiv (noting that none of the historically African-American denominations participated in the 2000 survey).

${ }^{83}$ See id at 209.

${ }^{84}$ Among reported adherents, however, there is significant agreement: the Southern Baptist Convention claims 83 percent $(3,368)$ of all adherents $(4,068)$; the next most numerous are United Methodists who claim 8 percent (330). See id (listing seven other groups, including one member of Baha'i).

${ }^{85}$ See notes $206-08$ and accompanying text. Whatever is the correct statutory interpretation, real estate agents are sometimes trained to avoid discussing demographics. See Rhonda L. Daniels, Fair Housing Compliance Guide 15-16 (1990) (regarding ethnic composition); Hannab v Sibcy Cline Realtors, 147 Ohio App 3d 198, 205, 769 NE2d 876, 881 (Ohio Ct App 2001) (describing an agent's practice of referring questions about religion to, for example, the Jewish Federation). But cf. Lior J. Strahilevitz, Exclusionary Amenities in Residential Communities, 92 Va L Rev $n 17$ (forthcoming 2006) (noting that racial steering seems to persist). 
help fill the gap. Like a Confederate battle flag hoisted above a public beach ${ }^{86}$ or a black-fist sculpture at a city's center, ${ }^{87}$ symbols can speak to the mix of decision makers on public questions along with the groups most likely to feel welcome.

The concept is readily extended to religion. As a start, signaling might be done by naming new cities after religious figures-Corpus Christi, Kiryas Joel, Rajneeshpuram, Saint Paul, San Diego. ${ }^{88}$ Demographics may change over the decades and renaming municipalities is disruptive, however. Today signaling might be accomplished by placing a large Latin cross at the center of town; ${ }^{89}$ depicting religious symbols on city signs, vehicles, and offices; ${ }^{90}$ carving religious messages into key government buildings; ${ }^{91}$ or zoning a church into a place of pride. ${ }^{92}$ In these ways, a political community can inform outsiders or remind insiders of the dominant local culture, and thus help maintain preferred spiritual demographics.

A modern example is the City of Republic in southwestern Mis-

\footnotetext{
${ }^{86}$ Compare Daniels v Harrison County Bd. of Supervisors, 722 So2d 136 (Miss 1998) (permitting the flag to stay, along with seven flags that formerly flew over what is now Mississippi).

${ }^{87}$ Compare Pat Zacharias, The Monuments of Detroit, Detroit News (2002) (describing and depicting a 24-foot-long, ungloved, horizontal, forearm-and-fist memorial dedicated to boxer Joe Louis).

${ }^{88}$ Compare Oregon $v$ City of Rajneeshpuram, 598 F Supp 1208 (D Or 1984) (involving Oregon's refusal to recognize a city in territory developed by followers of the Bhagwan Rajneesh).

${ }^{89}$ Compare Paulson v City of San Diego, 294 F3d 1124, 1125-28 (9th Cir 2002) (en banc) (involving a mountaintop plot with a 43 -foot-tall cross), cert denied, 538 US 978 (2003).

${ }^{90}$ Compare Robinson v City of Edmond, 68 F3d 1226, 1228 (10th Cir 1995) (invalidating a seal that incorporated a cross), cert denied, 517 US 1201 (1996); Harris $v$ City of Zion, 927 F2d 1401, 1412-15 (7th Cir 1991) (similar), cert denied, 505 US 1229 (1992); Friedman $v$ Board of County Comm'rs of Bermalillo, $781 \mathrm{~F} 2 \mathrm{~d}$ 777, 782 (10th Cir 1985) (en banc) (similar), cert denied, 476 US 1169 (1986); ACLU $v$ City of Stow, 29 F Supp 2d 845, 851-52 (ND Ohio 1998) (similar). But cf. Murray $v$ City of Austin, 947 F2d 147, 149, 155 (5th Cir 1991) (permitting a seal in light of its connection to Stephen Austin's coat of arms), cert denied, 505 US 1219 (1992).

${ }^{91}$ Compare Lambeth $v$ Board of Comm'rs of Davidson County, 407 F3d 266, 267-68 (4th Cir 2005) (upholding dismissal of a challenge to a decision to inscribe "In God We Trust" in 18-inch block letters on the facade of the County Government Center).

${ }^{92}$ Compare Dianna Smith, Landmark Cburcb Slated for Ave Maria Development, Naples Daily News (Mar 25, 2004) (describing plans for a town including Ave Maria University and a 150-foot-tall church with a 40-foot-tall body of Christ). According to one report, the founder of the university indicated the church "is there to remind the people "what we're about." Id. For lists of intentional communities with spiritual missions, see http:/ /directory.ic.org. For a network of Christian real estate agents, see http://www .hismove.com/about_us.htm.
} 


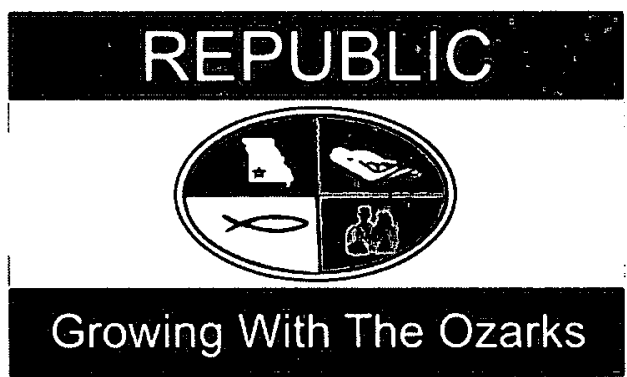

Fig. 1.-Official flag of the City of Republic, Missouri (1991-99). Source: "Flags of the World," http://www.crwflags.com/fotw/flags/us-morep.heml.

souri. ${ }^{93}$ After running a contest for a city flag and seal, the local government chose an elliptical shape with symbols in four quadrants. On the bottom half were images of a traditional nuclear family and a fish, or icbthys, commonly associated with Christianity (see fig. 1). The seal was displayed on city buildings, city vehicles, city stationery, and city-limit signs. ${ }^{94} \mathrm{~A}$ local minister declared that the ACLU had correctly associated the ichtbys with Jesus Christ, adding, "I say the line is drawn. Stay out of Republic. We're going to stand for Christian principles." "M Municipalities with exclusively secular missions could send messages equally overt. ${ }^{96}$

One feature of religious faith, moreover, makes public symbols especially useful devices for sorting. Individual religious commitments are relatively opaque. So even if municipalities had constitutional authority to exclude newcomers on the basis of religion-and they do not ${ }^{97}$ - signaling community character might still be valuable. It empowers outsiders to sort themselves based on

\footnotetext{
${ }^{93}$ See Webb v City of Republic, 55 F Supp 2d 994 (WD Mo 1999).

${ }^{* 4}$ See id at 995 ; id at 996 (quoting plaintiff's deposition testimony).

${ }^{95}$ Id at 999 (quoting comments at a board of aldermen meeting, and noting statements of two residents who claimed to have moved into the city because of the ichthys); see also id at 996 (explaining that plaintiff and her children moved out). The court enjoined use of the ichtbys, but on anti-proselytism grounds and without confronting sorting arguments. See id at 1000-01.

${ }^{96}$ See text at note 166 (discussing the southwest Missouri town of Liberal in the late $1800 \mathrm{~s})$.

${ }^{\text {"7 }}$ See Part III.A.1.
} 
privately held beliefs. ${ }^{98}$ In addition, subsets of outsiders will have greater difficulty clueing in on local religious culture and power. Such information is less easily available to secularists and nondenominational religionists. For members of religious groups, finding co-adherents is usually easy. If organized, these associations often advertise themselves, and might offer information about their comfort within a locality. Perhaps yet again unlike race, shared religious faith usually comes with a social network for adherents.

The endorsement test, however unwittingly, already inhibits such efforts to encourage sorting. Though formulated in the tradition of anti-proselytism, the test's outcomes are not sufficiently predictable to work around with certainty. And supporting religious symbols can be costly, aside from foregone residents. Organizations like the ACLU sometimes sue, attorney's fees are available if a lawsuit is successful, ${ }^{99}$ some municipalities are not wealthy, and those with only weak preferences for religious homogeneity are not likely to spend much to fight about it. ${ }^{100}$ The costs do cut both ways. Costly signals are credible signals, ${ }^{101}$ so current doctrine may facilitate signaling-maybe especially if the government loses in litigation. What better sign of loyalty to religious referents than a bull-headed defense of the state's commitment to religious symbols? On the other hand, there are Rule 11 risks for government lawyers, and few officials are both dedicated to uniformity in religious faith and as confrontational as Roy Moore, in light of the alternatives.

The point about alternatives is worth emphasizing. The case for outsider ignorance is easy to overstate. A variety of non-government conduct indicates local religious character: the number, denomination, and location of visibly religious structures (churches, synagogues, mosques, and so forth); Christmas lights on houses; fishlike emblems on cars; "WWJD" pendants on peo-

\footnotetext{
${ }^{98} \mathrm{~A}$ similar argument is elaborated with respect to private property rights in Lior J. Strahilevitz, Information Asymmetries and the Rights to Exclude, 104 Mich L Rev (forthcoming 2006) (discussing "exclusionary vibes").

${ }^{99}$ See 42 USC $\$ 1988$.

${ }^{100}$ See John Witte, Jr., Religion and the American Constitutional Experiment: Essential Rights and Liberties 173 (2000).

${ }^{101}$ See generally Eric A. Posner, Law and Social Norms 18-27 (2000).
} 
ple. ${ }^{102}$ Residents were already using the ichthys in southwest Missouri when Republic appropriated $i t ;{ }^{103}$ indeed, popular use made it possible for the symbol to serve a sorting function. Furthermore, unavailable information on religious demographics might be dependably correlated with available information, like voting patterns, race, and urban/rural setting. ${ }^{104}$ With effort, intelligent people can understand how a locality functions. That said, gradations of difficulty can make a difference in the extent of religious sorting, especially if it is a soft preference for substantial numbers of people. ${ }^{105}$ Accurate information about religion and local power, moreover, is especially challenging for an outsider to obtain.

\section{Anti-Sorting Principles}

The foregoing explains how religious symbols can be used to match a community-preferred character with individual religious identities. This is not a reason to interfere with the sorting process, however, least of all by constitutional law. Remember that Tiebout and his followers built a theory to justify intramunicipal uniformity of preferences, intermunicipal diversity in policy, and competition for residents. So geographic clustering by religion might be welfare enhancing, at least in the short run.

On the other hand, Tiebout sorting is not obviously entrenched in constitutional law. Although courts recognize a constitutional right of interstate migration ${ }^{106}$ and a qualified right of private associations to exclude people on some criteria, ${ }^{107}$ otherwise the Tiebout model is largely a question of subconstitutional policy.

${ }^{102}$ Compare William A. Fischel, The Homevoter Hypothesis: How Home Values Influence Local Government Taxation, Scbool Finance, and Land-Use Policies 60-61 (2001) (canvassing studies regarding the likelihood and impact of Tiebout sorting on public school quality).

${ }^{103}$ See Webb v City of Republic, 55 F Supp 2d 994, 999 (WD Mo 1999).

${ }^{104}$ Compare Larry L. Hunt and Matthew O. Hunt, Race, Region, and Religious Involvement: A Comparative Study of Whites and African Americans, 80 Social Forces 605, 615, 622 (2001) (reporting higher religious participation by African Americans than whites in the urban South).

${ }^{105}$ Compare Darren E. Sherkat, Religious Intermarriage in the United States: Trends, Patterns, and Predictors, 33 Social Sci Res 606, 611-13, 619 (2004) (reporting that more than half of surveyed Caucasian marriages were interfaith).

${ }^{106}$ See Saenz v Roe, 526 US 489, 500 (1999).

${ }^{107}$ See, e.g., Boy Scouts of Am. v Dale, 530 US 640, 659 (2000) (relying on interference with expressive mission). But cf. Roberts v United States Faycees, 468 US 609, 626-27 (1984) (finding insufficient burden on expressive interests to justify gender discrimination in voting). 
Neither persons nor groups are constitutionally entitled to a government that mirrors their policy preferences. Furthermore, constitutional case law plainly rejects state-facilitated sorting in some circumstances. Race is the familiar example. Today a city is constitutionally barred from designating residential space for whites only, even if every current resident supports the regulation and regardless of housing opportunities elsewhere. ${ }^{108}$ It is easy for us to see government-backed racial separation as part of a caste system, inhibiting individual liberty while reinforcing categorical distinctions between people that now seem irrational at best. Judicial concern with racial sorting, moreover, goes beyond officials outright forcing people to physically separate along racial lines. More subtle forms of encouragement or facilitation sometimes prompt judicial intervention. ${ }^{109}$

Is the Constitution a like impediment to separation along religious lines? May government officials intentionally encourage religious sorting across political boundaries? Knowingly facilitate such sorting? Decline to inhibit or remedy such sorting? Perhaps not, but these questions should not be answered by lockstep analogy to race cases. Religion and race are different phenomena. Decades of debating, litigating, legislating, politicking, and theorizing about sorting by race will not simply carry over to religion. For example: (1) our national experience and constitutional traditions differ with respect to religion and race; (2) race, as socially defined, is visible in a way that religion need not be; (3) religion, according to some conceptions, is connected to value systems and organization in ways that race need not be; (4) the number of religions in America is almost countless, whereas the concept of race might produce fewer salient divisions; (5) the desire or impetus for sorting may differ with respect to race and religion. These distinctions indicate the possibility of justifiably different treatment.

Without pretending to offer comprehensive solutions, the rest of this article digs into the constitutional law of religious sorting. It focuses on aspects of the problem that have been underappre-

\footnotetext{
${ }^{108}$ See also Runyon v McCrary, 427 US 160, 175-76 (1976) (permitting application of a civil rights statute to private schools with admissions policies that excluded racial minorities).

${ }^{109}$ See Anderson v Martin, 375 US 399, 402 (1964) (invalidating a requirement that candidate race be noted on ballots); Part III.B.1. (exploring possible versions of anti-sorting principles).
} 
ciated, including legal history, demographics, and doctrinal implications. Only a humble constitutional rule seems defensible at this time. But to understand the choice set, I will push the antisorting arguments much further. For example, an entirely plausible distinction between intentional government mandates and unwitting government facilitation of religious sorting will not be imposed at the outset. Accordingly, the discussion starts with precedent and the best justifications for an anti-sorting principle of any dimension, then turns to more concrete versions and possible implications, and closes with powerful objections to ambitious anti-sorting rules enforced by courts. ${ }^{110}$

\section{A. JUSTIFICATIONS}

1. Sorting precedent. There are two key building blocks in Supreme Court precedent for an anti-sorting principle. The first is a case about exclusion. Upon learning that a Santeria church was planned for construction within the City of Hialeah, a series of ordinances was adopted. ${ }^{111}$ Part of the Santeria faith calls for animal sacrifice, and the practical effect of the ordinances was to outlaw "ritual" animal sacrifice without threatening kosher butchers. ${ }^{112}$ The Court unanimously held the ordinances invalid. Going out of its way to teach the locals a lesson, the majority explained that Santeria is a religion for First Amendment purposes even though the city did not argue otherwise. ${ }^{113}$ The opinion opened with the observation that local officials "did not understand, failed to perceive, or chose to ignore the fact that their official actions

\footnotetext{
${ }^{110}$ Religious sorting is also a pure policy question, and there are familiar objections to the Tiebout model in any case. Critics argue that, for example: (1) the original model needs a political system, and its assumptions-such as perfect information, no externalities, and dividends providing all income for the citizenry-must be loosened; (2) subsequent empirical work suggests that residential choices are primarily driven by factors other than government services and taxes, like family and employment needs; and (3) Tiebout sorting is normatively controversial if one is committed to certain notions of social equality, voicebased democracy, and public-spirited citizenship. See, e.g., Gerald E. Frug, City Making: Building Cities Without Walls 168-73 (1999); Paul W. Rhode and Koleman S. Strumpf, Assessing the Importance of Tiebout Sorting: Local Heterogeneity from 1850 to 1990, 93 Am Econ Rev 1648 (2003); Susan Rose-Ackerman, Beyond Tiebout: Modeling the Political Economy of Local Government, in George R. Zodrow, ed, Local Provision of Public Services: The Tiebout Model After Twenty-five Years 56-57 (1983). But only some of the standard objections are relevant here. They must plausibly relate to constitutional law.

"'See Church of the Lukumi Babalu Aye, Inc. $v$ City of Hialeah, 508 US 520, 526 (1993).

${ }^{112}$ See id at 535-36.

${ }^{113}$ See id at 531; see also id at 541-42 (opinion of Kennedy, J, joined by Stevens, J).
} 
violated the Nation's essential commitment to religious freedom." 114

Commentators discuss the Santeria case as a matter of free exercise, ${ }^{115}$ and it is surely that. Presumably the same result would obtain if the state of Florida or the federal government adopted the same rules for animal sacrifice. But in the spirit of Tiebout, the Court might have told the newcomers to sort themselves into a more accepting municipality. ${ }^{116} \mathrm{Or}$, recognizing that the City of Hialeah could not have guaranteed Santeria space in any other jurisdiction, the Court might have distinguished a hypothetical statewide program that achieved such a guarantee. But nothing in the Court's decision is so pro-sorting. It does not suggest that a municipality may expel a disfavored religion from its territory as long as another municipality stays open. To the contrary, the opinion-protecting "the Nation's essential commitment" to religious liberty ${ }^{117}$-indicates opposition to sect-targeted and governmentbacked efforts to achieve local homogeneity. For federal constitutional purposes, then, religion looks more like race than wealth: localities may more or less explicitly zone for homogeneity in the latter but not the former. ${ }^{118}$ The Court would blanch at overt government efforts to restrict migration of African-Americans to select communities even if 99 percent of residential property within the region remained open. A different result seems unlikely for denominations like Santeria. ${ }^{119}$

${ }^{114}$ Id at 524 .

${ }^{115}$ See, e.g., Schragger, 117 Harv L Rev at 1852 (cited in note 13).

${ }^{116}$ Compare City of Renton v Playtime Theatres, Inc., 475 US 41, 53-54 (1986) (municipality could isolate sexually explicit movie theaters to 5 percent of the city's total area, even if that left no commercially viable locations); Miller $v$ California, 413 US 15, 24 (1973) (permitting community standards to help define obscenity); see also City of Erie v Pap's A.M., 529 US 277, 301-02 (2000) (plurality opinion) (municipality could apply a public nudity ban to nude dancing in strip clubs). But cf. Schad v Borougb of Mt. Epbraim, 452 US 61, 76 (1981) (municipality violated speech rights by zoning out live entertainment, including nude dancing at an adult bookstore-at least in the absence of evidence that "the kind of entertainment appellants wish to provide is available in reasonably nearby areas"); Mary Anne Case, Community Standards and the Margin of Appreciation, 25 Human Rts L J 10, 10-11 (2005) (noting that obscenity law seems to be an outlier).

${ }^{117}$ Lukumi, 508 US at 524 (emphasis added).

${ }^{118}$ See Village of Arlington Heights v Metropolitan Housing Dev. Corp., 429 US 252 (1977); Buchanan v Warley, 245 US 60, 70-71, 81-82 (1917).

119 The Court stressed that Santeria had been purposefully and effectively singled out by the city for disfavor, see Lukumi, 508 US at $534,545-46$, thereby distinguishing broader legislation with an equally burdensome impact when applied to ritual sacrifice. But this problem of effective substitutes for overt discrimination is not special to anti-sorting principles. 
Even so, the Hialeah decision is not entirely anti-sorting. In fact it might be read as pro-sorting but anti-subordination. In the spirit of Carolene Products ${ }^{120}$ rather than Charles Tiebout, the Court might have been protecting the interests of non-mainstream religions to sort themselves however they wish. Perhaps Santeria's victory means that the local political unpopularity of a migrant's religion, like her race, is not something she should have to worry about while sorting. But even with a useful concept of "minority religion" within a multitude of faiths, this reading is not quite right. The Court's concern goes beyond empowering minorities to join a locality that prefers to maintain its religious composition.

The point is made by a second and more controversial case. A year after the Hialeah decision, the New York legislature was rebuked for drawing a new public school district at the request of the Satmar Hasidim. ${ }^{121}$ The district's boundaries would have matched the Satmars' residential enclave in the Village of Kiryas Joel, and the Court balked at officials consciously aligning political institutions with religious geography. ${ }^{122}$ This was true even though both the Satmars and the adjacent community were probably grateful for the partition. The former wanted the new district to provide special education services apart from non-Satmar students, who were a source of discomfort and humiliation for their children. ${ }^{123}$

The ramifications of the case are unclear, however. The decision did not entail invalidation of the Satmars' village, for example, even though it was religiously homogenous by any standard. ${ }^{124}$

\footnotetext{
${ }^{120}$ See United States $v$ Carolene Products Co., 304 US 144, 153 n 4 (1938).

${ }^{123}$ See Board of Educ. of Kiryas 7oel Vill. Sch. Dist. $v$ Grumet, 512 US 687, 690 (1994).

${ }^{122}$ See id at 698-702 \& n 6 (plurality opinion) (condemning the act for districting by religious criterion); id at 711 (Stevens, J, concurring) (asserting that the act "affirmatively supports a religious sect's interest in segregating itself"); id at 728 (Kennedy, J, concurring) ("[G]overnment may not use religion as a criterion to draw political or electoral lines."); see also Larkin v Grendel's Den, Inc., 459 US 116 (1982) (invalidating a delegation to churches of veto power over liquor licenses); cf. Lynch, 465 US at 687-88 (O'Connor, J, concurring) (condemning "excessive entanglement with religious institutions, which may ... foster the creation of political constituencies defined along religious lines"); Lupu, 96 Colum L Rev at 108-09 (cited in note 13) (noting residency incentives for Satmars arguably created by the special district).

${ }^{123}$ See Kiryas 7oel, 512 US at 692; see also id at 691-93 (noting earlier conflicts over zoning and special education at an off-site location); note 2 above (noting Aguilar was later overruled).

${ }^{124}$ See Kiryas 7oel, 512 US at 703 n 7 (distinguishing the village); id at 729-30 (Kennedy, J, concurring) (same).
} 
Why not? The majority's worry was that state officials purposefully singled out the Satmars for special treatment in creating the school district; but that problem does not apply to the village. ${ }^{125}$ "State action" was needed to get either one, of course. But the state might have been too conscious of sectarian beneficiaries in dealing with the school district, and failed adequately to assure empathy for similarly situated communities. By contrast, the village's boundaries were generated by a process facially neutral with respect to religion. Any group could seek municipal status by that process. ${ }^{126}$ If we assume the Satmar village is constitutionally permissible, perhaps the state may facilitate sorting by all groups, as long as it does not purposefully facilitate religious sorting. On the other hand, an anti-subordination principle might reenter the picture here; it could restrict the benefits of municipal status for religiously monolithic communities to systematic losers in the political process. After all, the Satmars traveled a long way before reaching Kiryas Joel, ultimately seeking village status to escape restrictive zoning ordinances burdening their way of life. The character of any principle underlying the case is thus undefined.

One limit to the Court's opposition to religious sorting should be emphasized here. The attention is on religious cleavages that match political boundaries, but not all boundaries will be policed. This is a fair inference from race cases. A majority of the Court has been concerned when officials draw legislative districts to match racial demographics. ${ }^{127}$ Yet dissenters in those cases-all of whom voted to invalidate the Satmars' special school districtindicated that religion is a presumptively valid basis on which to draw legislative districts. ${ }^{128}$ The majority did not disagree on the

${ }^{125}$ See id at 690; id at 717 (O'Connor, J, concurring) (indicating a preference for accommodations that benefit both religious and secular groups); see also Grimet v Pataki, 720 NE2d 66 (NY 1999) (striking a subsequent, nominally neutral statute), cert denied, 528 US 946 (1999).

${ }^{126}$ But cf. Oregon v City of Rajneeshpuram, 598 F Supp 1208 (D Or 1984) (refusing to dismiss a state's constitutional objection to the formation of a city by followers of the Bhagwan Rajneesh, which would have been solely composed of a county road and churchowned property).

${ }^{127}$ See, e.g., Miller $v$ fobnson, 515 US 900, 910-11 (1995).

${ }^{128}$ See id at 944-45 (Ginsburg, J, dissenting) ("Our Nation's cities are full of districts identified by their ethnic character-Chinese, Irish, Italian, Jewish, Polish, Russian, for example."); Shaw v Reno, 509 US 630, 679 (1993) (Stevens, J, dissenting) ("If it is permissible to draw boundaries to provide adequate representation for rural voters, for union members, for Hasidic Jews, for Polish Americans, or for Republicans, it necessarily follows that it is permissible to do the same thing for members of the very minority group whose 
religion point, ${ }^{129}$ and nobody contended that such districting needed to relieve religious subordination. Why the free pass on legislative districts?

A simple explanation turns on the different functions served by jurisdictional boundaries. In legislative districting, officials mold the membership of a decision-making body drawn from a given citizenry. Those representatives later assemble and make policy. District lines no doubt affect the legislature's composition, but homogeneity within districts will not necessarily have a serious impact on influence within the assembly. In drawing state and municipal boundaries, however, the citizenry itself is defined. This is important as long as state and local governments retain significant decision-making authority of their own. ${ }^{130}$ And homogeneity within such polities is undeniably connected to influence over what is taught in public schools, who enjoys exemptions from regulation, which books show up in public libraries, who runs the local courts, and so on. Religious anti-sorting principles are aimed at the manufacture of such polities.

2. Sorting experiments and legal change. Details aside, the Satmar and Santeria decisions indicate that special government efforts to promote religious homogeneity are sometimes invalid. But can we justify, or at least account for, the precedent? Is there a legitimate constitutional foundation for anti-sorting principles?

Arguments from plain text or original meaning at the founding are unlikely suspects. The First Amendment's religion clauses were drafted as restraints on "Congress" and, by logical extension, the rest of the federal government. ${ }^{131}$ The posture of state and local governments toward religion was an issue for them to resolve. ${ }^{132}$ As such, the Federal Constitution of 1791 was at most agnostic

history in the United States gave birth to the Equal Protection Clause."); Mary Anne Case, Lessons for the Future of Affirmative Action from the Past of the Religion Clauses? 2000 Supreme Court Review 325, 340-41.

${ }^{129}$ See Miller, 515 US at 918 (indicating that respect for "communities defined by actual shared interests" helps defeat race-based equal protection attacks on legislative districts).

${ }^{130}$ Compare Richard Thompson Ford, Geograpby and Sovereignty: Furisdictional Formation and Racial Segregation, 49 Stan L Rev 1365 (1997) (arguing that racial segregation at the municipal level is more troubling than in the electoral districting context). Constituent services do connect the function of electoral districts with municipalities, however.

${ }^{131}$ The guarantee might be a dead-letter otherwise, or the conduct of other branches might be traced back to congressional authorization. See also US Const, Art VI, cl 3 (barring religious tests for federal office).

${ }^{132}$ See generally Akhil Reed Amar, The Bill of Rights: Creation and Reconstruction 32-34, 41 (1998). 
about religious sorting. And the explicit promise that Congress would make no law "respecting" an establishment of religion made the document arguably pro-sorting. ${ }^{133}$ Whatever else the clause meant when ratified, it indicated restraints on the ability of the federal government to interfere with state religious "establishments." So a constitutional anti-sorting norm depends on movement since 1791. The importance of the Fourteenth Amendment and subsequent constitutional theory is examined below. However, the argument should begin with government policy predating the Constitution and the dramatic legal change thereafter. This history is sufficiently intriguing that countless scholars have traced and retraced it. But major developments that are crucial from a sorting perspective are not highlighted in contemporary legal scholarship.

The fact is that our country ran an extended experiment with religious sorting policies at the state and local level. These experiments were intimately associated with official religious "establishments," and they did not survive. This history is commonly seen as a regrettable episode of intolerant deprivations of religious liberty and equality - a misstep to be forgiven in light of a population so much less diverse than today's. ${ }^{134}$ But that homogeneity was partly the result of purposeful official efforts to sculpt religious demographics in the New World. Religious establishments were part of a dynamic migration system. Less welcoming atmospheres tend to ward off the less welcome, while attracting the favored class. A religious-sorting perspective on American history emphasizes these dynamics.

The British colonies provided havens for Protestants, who had strong incentives to sort themselves out of Europe, and for those who thought the Church of England was corrupt. ${ }^{135}$ The colonies were sometimes advertised as such. ${ }^{136}$ At the same time, these

${ }^{133}$ Compare US Const, Art I, $\$ 9$, cl 1 (barring Congress from prohibiting migration of persons that existing States thought proper to admit, until 1808).

${ }^{134}$ Compare, e.g., Leonard W. Levy, The Establishment Clause: Religion and the First Amendment 9, 27 (1986) (missing the sorting dynamic when asserting that a State establishment of Christianity or Protestantism in 1790 would have been "for practical purposes, a comprehensive or non-preferential establishment).

${ }^{135}$ See Thomas J. Curry, The First Freedoms: Church and State in America to the Passage of the First Amendment 3 (1986); 1 Anson P. Stokes, Church and State in the United States 227 (1950).

${ }^{136}$ See, e.g., Walter A. Knittle, Early Eighteenth Century Palatine Emigration 12, 22-31 (1937); id at 20 ("[In Germany,] Pennsylvania was the best advertised province and it was mainly due to the liberal use of printer's ink."). 
outposts executed the most severe forms of intolerance against other faiths. Certainly part of the story is about religious liberty simpliciter. Regulation of religious practices, such as rules limiting who could preach or perform legally recognized marriage ceremonies, ${ }^{137}$ were obviously impositions on minorities within a given colony. But such regulation and promotion also were mechanisms that encouraged sorting during periods of mass migration. ${ }^{138}$ For a time, some colonies even adopted immigration laws to exclude or deport those of the wrong religion. ${ }^{139} \mathrm{~A}$ Virginia policy excluded Catholics and Puritans; Massachusetts Bay Colony banished Quakers and others. ${ }^{140}$ In the latter case, Quakers faced the death penalty for returning to Massachusetts, not simply for their heresy. ${ }^{141}$ The colony preferred conformity, to be sure, but the primary tool seems to have been population control rather than conversion.

These formal exclusions were abandoned before separation from the Crown, but efforts to shape the religious population continued. Several early state governments officially preferred sets of religious beliefs and practices. For example, South Carolina's 1778 Constitution declared Protestantism the state's established religion. ${ }^{142}$ To achieve incorporated status, religious societies would have to agree that Christianity is the "true religion," the New Testament is "of divine inspiration," and there is a "future state of rewards

${ }^{137}$ See Michael W. McConnell, Establishment and Disestablishment at the Founding, Part I: Establisbment of Religion, 44 Wm \& Mary L Rev 2105, 2162, 2165-67, 2175 (2003).

${ }^{138}$ See Stokes, 1 Cburch and State at 227-28 (cited in note 135) ("From the British government's standpoint an object always in mind was a desire to prevent Roman Catholicism . . . from getting the upper hand in North America."); McConnell, $44 \mathrm{Wm}$ \& Mary L Rev at 2161-62 (cited in note 137) (discussing Massachusetts Bay Colony).

${ }^{139}$ See Edward P. Hutchinson, Legislative History of American Immigration Policy 1798-1965 at 389-90 (1981); Emberson E. Proper, Colonial Immigration Laws: A Study of the Regulation of Immigration by the English Colonies in America 17-18, 26-27, 58-61 (1900) (finding a general tendency to deny or discourage Catholic immigration).

${ }^{140}$ See John T. Noonan, Jr., The Lustre of Our Country: The American Experience of Religious Freedom 51-53 (describing Massachusetts's policy from 1656 to 1681); McConnell, $44 \mathrm{Wm}$ \& Mary L Rev at 2117, 2119 (cited in note 137) (describing Virginia's policy and its apparent success regarding Catholics).

${ }^{141}$ See Richard P. Hallowell, The Quaker Invasion of Massachusetts 139-43 (3d ed 1884) (reproducing laws from 1658 and 1661); Noonan, The Lustre of Our Country at 52-53 (cited in note 140); see also Curry, The First Freedoms at 20-21 (cited in note 135) (noting regional opposition to Quaker presence).

${ }^{142}$ See SC Const, Art XXXVIII (1778), reprinted in 6 The Federal and State Constitutions: Colonial Cbarters, And Other Organic Laws of the States, Territories, And Colonies Now or Heretofore Forming the United States of America 3255-57 (Francis N. Thorpe ed., 1909) (hereafter Thorpe). 
and punishments." ${ }^{143}$ Such provisions were liberal compared to colonial policy, but they still made statements about the religious commitment expected of inhabitants. ${ }^{144}$

More important, some colonies and states taxed people for the specific purpose of funding preferred churches or ministers. Virginia famously ran such a system for a time. Massachusetts, Connecticut, and New Hampshire authorized municipalities to select a minister for tax-and-transfer, thereby further decentralizing without rejecting religious establishments. ${ }^{145}$ From a sorting perspective, these programs might be superior to immigration laws. The latter must have been difficult to enforce insofar as religious commitments can be sustained without social visibility-a fact that helps explain severe penalties for return after banishment. A tax, in contrast, can be levied on all or many residents and the proceeds then directed to an identifiable religious organization or figure. ${ }^{146}$ In other words, officially preferred beneficiaries were probably easier to identify than disfavored religionists. In addition, financing schemes that allowed people to opt out, or to direct their tax contribution to minority religions, ${ }^{147}$ can also facilitate sorting. To choose one of these options is to identify oneself as a dissident. Adherents to minority religions might well prefer to remain anonymous, and so either conform or go elsewhere.

Not all states aimed to be narrowly sectarian enclaves. One could avoid the Congregational influence in New England and the Anglican establishments of some southern states by settling in Delaware, Pennsylvania, New Jersey, or Rhode Island. They billed themselves as relatively open political societies. ${ }^{148}$ The variance in

\footnotetext{
${ }^{143} \mathrm{Id}$.

${ }^{144}$ See also, e.g., Mass Declaration of Rights, Art II (1780) ("It is the right as well as the duty of all men in society, publicly, and at stated seasons, to worship the Supreme Being . . . "), reprinted in 3 Thorpe at 1889 (cited in note 142); cf. Va Declaration of Rights $\$ 16$ (June 12,1776) (" $[\mathrm{I}] \mathrm{t}$ is the mutual duty of all to practise Christian forbearance, love, and charity towards each other."), reprinted in 7 Thorpe at 3814 (cited in note 142); Proper, Colonial Immigration Laws at 27 (cited in note 139) (noting voting rights restrictions).

${ }^{145}$ See generally Gerard V. Bradley, Cburch-State Relationships in America ch 2 (1987); Levy, The Establishment Clause at 15-24 (cited in note 134) (noting exemptions for certain sects at certain times).

${ }^{146}$ Not that tax collection was easy in that era. See Robert A. Becker, Revolution, Reform, and the Politics of American Taxation, 1763-1783 at 7, 116 (1980).

${ }^{147}$ See Levy, The Establishment Clause at 27-28 (cited in note 134) (describing Massachusetts law in 1780).

${ }^{148}$ See generally id at $1,5,9-10,25-26$.
} 
church-state policies offered choices of politico-religious culture. Many people must have made decisions accordingly. ${ }^{149}$ Forced to characterize the early American law of religion as anti-liberty or pro-sorting, one could easily favor the latter.

Either way, the formal establishments soon collapsed. Any Anglican establishment was poorly situated to outlive the Revolution. Other schemes failed as well. For instance, South Carolina's proestablishment clauses were repealed in $1790 .{ }^{150}$ Massachusetts' system of locally established faiths, which outlasted all the other formal establishments, was abolished in $1833 .{ }^{151}$ Buffeted by immigration, additional sources of religious diversity, and competing economic interests, ${ }^{152}$ the impulse for religiously closed states softened. Interfaith animosity was not eliminated, of course. If nothing else, the experience of Catholics in the nineteenth century defeats that claim. ${ }^{153}$ And religiously restrictive covenants were used to shape local demographics long after the original establishments were discontinued. ${ }^{154}$ Yet the idea of state-orchestrated partition of religious groups seems to have lost legitimacy in relatively short order.

In fact, a sign of the change can be found in a passage of Justice Harlan's dissent in Plessey $v$ Ferguson. It put state-mandated religious segregation on a list of shocking hypotheticals that the supporters of racial segregation were challenged to distinguish:

[T] $f$ this statute of Louisiana is consistent with the personal liberty of citizens, why may not the state require the separation

\footnotetext{
${ }^{149}$ See Finke and Stark, The Churching of America at 27-33, 285-89 (cited in note 22) (extrapolating from data on the number and location of congregations and showing regional variation).

${ }^{150}$ See SC Const, Art I, $\$ \$ 4,6,8,23$, Art II, $\$ \$ 2-3$, Art VIII (1790), reprinted in 6 Thorpe at 3258-62, 3264 (cited in note 142); Levy, The Establisbment Clause at 51 (cited in note 134).

${ }^{151}$ See Mass. Articles of Amend. XI (1833), reprinted in 3 Thorpe at 1914 (cited in note 142); see generally Douglas Laycock, "Nonpreferential" Aid to Religion: A False Claim About Original Intent, 27 Wm \& Mary L Rev 899-901 (1986).

152 See Schuck, Diversity in America at 261 (cited in note 13); Steven D. Smith, Getting Over Equality 21 (2001) (asserting that pluralism, not doctrine, produced religious freedom).

${ }^{153}$ See, e.g., Philip Hamburger, Separation of Church and State ch 8 (2002); Kurt T. Lash, The Second Adoption of the Establishment Clause: The Rise of the Nonestablishment Principle, 27 Ariz St L J 1085, 1119-20 (1995).

${ }^{154}$ See William E. Nelson and Norman R. Williams, Suburbanization and Market Failure: An Analysis of Government Policies Promoting Suburban Growth and Etbnic Assimilation, 27 Fordham·Urban L J 197, 215 (1999).
} 
in railroad coaches of native and naturalized citizens of the United States, or of Protestants and Roman Catholics? ${ }^{155}$

This statement might support only a narrow anti-sorting rule, involving legally coerced segregation by religion. But it's a start.

3. Anti-sorting in theory. Entrenching every perceived resolution of political conflict is no way to do constitutional law, of course. Anti-sorting principles need arguments to distinguish them from other trends. As a matter of constitutional text, the critical sources are the state-restraining provisions of the Fourteenth Amendment. But because that text is so underspecified, and because its inspiration was chattel slavery, a religion-oriented anti-sorting norm must be reinforced with a broader or different constitutional theory. This is not the place for a fully articulated sorting theory or an end to the "incorporation" debate. Normative and empirical uncertainties strongly caution against a robust anti-sorting principle, anyway. Yet with a little effort, we can see the structure of the argument. And this structure will further the equally challenging task of grinding out concrete versions of the principle.

There are two promising routes to a constitutional anti-sorting principle. Both rely on implications of the Fourteenth Amendment and Reconstruction. ${ }^{156}$ The first route is conventional yet synergistic. The concept of "law respecting an establishment of religion" would be borrowed from the First Amendment and converted into a prohibition on state action by one or more clauses in the Fourteenth. The second route does not directly rely on First Amendment concepts. Instead, the Fourteenth Amendment itself underwrites an antisorting norm. Either way, the argument is above and beyond the particularities of Establishment Clause interpretation. These two lines of the argument can then be joined with modern political theory, concern for consequences, and empirical data. ${ }^{157}$

${ }^{155}$ Plessy $v$ Ferguson, 163 US 537, 558 (1896) (Harlan, J, dissenting).

${ }^{156}$ These arguments are heavily influenced by the work of Akhil Amar, Christopher Eisgruber, and Kenneth Karst. See Amar, The Bill of Rights at 248-57 (cited in note 132); Eisgruber, Madison at 351-355, 371-78, 381-88 (cited in note 13); Christopher L. Eisgruber, Etbnic Segregation by Religion and Race: Reflections on Kiryas Foel and Shaw v. Reno, 26 Cumb L Rev 515, 515-22 (1996); Eisgruber, Assimilation at 92 (cited in note 13); Christopher L. Eisgruber, Political Unity and the Powers of Government, 41 UCLA L Rev 1297, 1323-28 (1994); Kenneth L. Karst, 7ustice O'Connor and the Substance of Equal Citizenship, 2003 Supreme Court Review 357; Karst, 27 Harv CR-CL L Rev at 512-25 (cited in note 45 ).

${ }^{157}$ Conventional Religion Clause theories are not terribly useful here. See Hugh Baxter, Managing Legal Change: The Transformation of Establisbment Clause Law, 46 UCLA L Rev 
a) The first path depends on certain understandings of both the First and Fourteenth Amendments. The latter explicitly restrains state action in multiple ways that might be relevant: protecting privileges or immunities, guaranteeing liberty with due process, demanding equal protection of the laws; even the grants of national and state citizenship can be relied on. A free-exercise norm, moreover, fits easily within these concepts. There is even Fourteenth Amendment drafting history to that effect. ${ }^{158}$ Excluding people or organizations from states or municipalities, such as Hialeah's attempt to prevent Santeria's immigration, is thus relatively easy to prohibit under the Fourteenth Amendment. The result in the Santeria case shielded a sect from a ritual-targeting government prohibition. But for discretionary benefits like a school district for the Satmars, the constitutional problem is harder to see (at least if equal protection norms are satisfied). In some ways the new district promoted religious liberty-perhaps not a system of liberty in which multiple sects thrive and interact, but surely the religious autonomy of the Satmars was served. It is not even clear that the new district would have required substantial additional tax dollars from outsiders who might object. This suggests that more must be done to articulate a non-establishment norm that plausibly can be appropriated by the Fourteenth Amendment. After all, the Establishment Clause of the First Amendment was a federalism-promoting concession to the states that resists an easy transplant into the Fourteenth.

The best argument on this track is that the American view of religious establishments changed between 1791 and 1868. Perhaps it moved from local option to liberty killer. Even ignoring stare decisis, there is material to support this thesis. However disconnected disestablishment was from the notion of religious liberty at the founding, these ideas were sometimes coupled by the time the

343, 351 n 32 (1998) (collecting theories). "Substantive neutrality," which prefers to minimize the impact of state action on religious choices, always has a difficult time selecting a subset of government conduct to monitor, and it is not immediately clear what baseline is best for sorting purposes. More important, a simple neutrality theory-whether "substantive" or "formal"-will not explain why federal action seems to be treated more leniently than analogous state and local action. Theorists seeking to maximize religious liberty (e.g., those who are pro-"accommodation" plus anti-"coercion") cannot be sure whether sorting across political boundaries diminishes religiosity or alters its mix in a problematic way. Finally, "strict separation" would be highly concerned with overt state efforts to build religion-sustaining political enclaves. But not much is clear beyond that and, in any event, the theory is infeasible in its strong forms and not particularly popular in the courts, anyway.

${ }^{158}$ See Amar, The Bill of Rights at 253 (cited in note 132). 
Fourteenth Amendment was ratified. ${ }^{159}$ In fact, a few state and territorial constitutions even mimicked the federal Establishment Clause and its "law respecting" language. ${ }^{160}$ Thomas Cooley's 1868 treatise summarized state constitutions in just those terms. ${ }^{161}$ It is extremely unlikely that these clauses reflected yet another structural decision to decentralize religious questions to municipalities, and they were certainly not cross-jurisdictional protection for other states. A better explanation lies in the shift away from formal establishments among the original states, along with changing political values in the West. ${ }^{162}$ Government was by no means disconnected from religion in the 1800s; part of the allergy to "church"-state connection, moreover, was anti-Catholicism that accompanied new waves of international immigration. ${ }^{163}$ But subnational "establishments" became incompatible with prevailing notions of the proper relationship between government and religion. And we now know that sorting accompanied state and colonial programs regarding religion, we might conclude that governmentpropelled religious messages are a component of any "establishment" worthy of the name, and we are in any case much closer to placing an anti-sorting norm within the Fourteenth Amendment. ${ }^{164}$

Once the values of deregulated religious liberty and non-establishment are imported, anti-sorting is not only a matter of historical analogy. The principle may be prophylactic, and here there is a connection with anti-proselytism. Monitoring the conduct of officials within local religious enclaves can be difficult. Without ef-

\footnotetext{
${ }^{159}$ See Lash, 27 Ariz St LJ at 1133 (cited in note 153) (asserting that "by Reconstruction, northern state courts had translated the prohibition of the original Establishment Clause to be an expression of fundamental religious liberty"); see also id at 1130 .

${ }^{160}$ See id at $1133 \&$ \& 224.

${ }^{161}$ See Thomas M. Cooley, A Treatise on the Constitutional Limitations Wbich Rest Upon the Legislative Power of the States of the American Union 469-71 (1868) (distinguishing "solemn recognition of a super-intending Providence in public transactions and exercises as the general religious sentiment requires"-at least to meet secular goals of public morality and order).

${ }^{162}$ See Amar, The Bill of Rights at 248-52 (cited in note 132).

${ }^{163}$ See generally Hamburger, Separation of Cburch and State, ch 8 (cited in note 153); see also Adam M. Samaha, Separation Rhetoric and Its Relevance, 19 Const Comm 713, 728-30 (2002) (book review) (analyzing the muted relevance of the failed Blaine Amendment).

${ }^{164}$ Compare McConnell, $44 \mathrm{Wm} \&$ Mary L Rev at 2131 (cited in note 137) (asserting that "establishment" means "the promotion and inculcation of a common set of beliefs through governmental authority" and noting variations in coerciveness). The best definition of "establishment" and the propriety of prophylactic measures beyond it are controversial questions, but no less difficult for anti-proselytism principles.
} 
fective monitoring, however, these enclaves can disrupt political choices at the state and national levels. Furthermore, sorting will often be imperfect. This was true even under colonial regimes. ${ }^{165}$ Religious faith can be relatively invisible if an individual so chooses, while non-religious reasons plainly affect location decisions. Thus a municipality dominated by one sect might still have non-conformists to deal with. Leaving the law to such imperfectly sorted religious enclaves can therefore threaten social policy. Nor is the threat restricted to sectarian proselytizing and ostracism. There is likewise reason to worry that imperfectly sorted secular enclaves will disregard constitutional guarantees of religious liberty. And the more generous one is with free exercise rights, the more worried one should be about secular dominance within a political community. As such the sectarian vision of Republic, Missouri, in the 1990 s was not categorically different from the atheistic aspiration of Liberal, Missouri, in the 1880 s—a town more than happy to declare its official opinion that "MAN'S SAVIOR MUST BE MAN ALONE."166

Fears persist, moreover, even when sorting is complete. A nightmare scenario is suggested by charges against the Fundamentalist Church of Jesus Christ of Latter Day Saints in Colorado City, Arizona. Members allegedly sorted themselves into relative isolation, minimized access to communications technology, taught theories of racial superiority, subordinated girls to patriarchal domination, banished hundreds of teenage boys to maintain a gender imbalance for polygyny, used government officials to further Church diktats concerning romantic relationships, and diverted tax dollars intended for public schools to Church operations. ${ }^{167}$ In fact,

${ }^{165}$ See Part III.A.2.; cf. Lee Anne Fennell, Revealing Options, 118 Harv L Rev 1399, 1456-57 (2005) (noting the constraints of bundled choices, change of preferences over time, and transition costs of sorting and re-sorting if local legal rules are flat and fixed).

${ }^{166}$ Philip Hamburger, Illiberal Liberalism: Liberal Theology, Anti-Catholicism, and Church Property, 12 J Contemp Legal Issues 693, 702 n 29 (2002) (citation omitted) (adding that "the happiest and best community is that one which is the freest from the dogmas of religion"). Séances were popular in the town, however. See J. P. Moore, This Strange Town-Liberal, Missouri 74 (1963).

${ }^{167}$ See David Kelly, Lost to the Only Life They Knew, L.A. Times (June 13, 2005) at A1; Petition for Appointment of Receiver, In re Colorado City Unified Sch. Dist. No. 14, Case No. 2005-001, at 8-10 (Aug 12, 2005) (filed with the Arizona State Board of Education) (noting that all school board members and administrators are FLDS members, and charging them with mismanaging district property to the benefit of FLDS). The Attorney General's petition alleges, for example, that the district purchased an airplane and later was unable to pay teachers' salaries. See id at 4,8 . 
"diversion" loses meaning in this context. If critics are correct about Colorado City, local government authority is now an arm of the Church and wielded to achieve religious goals. This fits any plausible definition of religious establishment. Separation of church and state might be a poor slogan for the Establishment Clause, but church-state integration is certainly not the vision. Anyway, the important argument for anti-sorting principles is that religious homogeneity makes such constitutional violations more likely. And in an interconnected society with a substantial welfare state, "complete exit" of religious groups is more difficult to achieve. ${ }^{168}$

Religious sorting therefore should be most distressing to those who support robust versions of anti-establishment norms. However appealing one might think it to rope off "the government" from religious symbols, religious justifications for public policy, and subsidies benefiting religious institutions, those goals will be harder to obtain if the community is monolithically dedicated to one version of religious faith. ${ }^{169}$ All the more so at the local level where the public/private line, often by design, is faintest.

b) The argument for a principle disfavoring religious sorting is bolstered by an alternative path. Post-Reconstruction ideals of citizenship and nationalism may support it. Kenneth Karst is a leader here. He forged a theoretical connection between race and religion through the concept of equal citizenship. ${ }^{170} \mathrm{He}$ did so in service of nationalism-some bare minimum of national identity and civic unity in a multicultural country, ${ }^{171}$ which stands against exclusionary or polarizing use of race and religion in politics. Race might be more salient in America, but religion is another tool with which politicians and officials can divide the country. Engineering a desired composition of religion within a political boundary is a literal example of this feared partition. And one can reach these conclusions without specifying the best interpretation of the First Amendment. $^{172}$

\footnotetext{
${ }^{168}$ Compare Greene, 96 Colum L Rev at 8, 17 (cited in note 13) (discussing complete exit and partial exit).

${ }^{169}$ An attempt to hold all of these positions, and grant legislatures the option to authorize political enclaves for "minority" religions, is id at 24-26, 83 n 329, 85 n 335, 86.

${ }^{170}$ See Karst, 27 Harv CR-CL L Rev at 512-25 (cited in note 45).

${ }^{171}$ See Kenneth L. Karst, Belonging to America: Equal Citizenship and the Constitution 101, 173 (1989).

${ }^{172}$ Compare Amar, The Bill of Rights at 254 (cited in note 132) (concluding that Alabama could not declare itself "the White Supremacy State" and suggesting the same for Utah declaring itself "the Mormon State").
} 
Yet insofar as racial sorting implicates fears of perpetual subordination, religious sorting is distinct. Perhaps few believe that race is a normatively defensible category for many purposes and all else equal, instead of a social fact or a tool for organizing disadvantaged groups. But religion is another story. It is far more difficult to demonstrate that society would be better off with the extermination of religion as a category. Furthermore, free-exercise values suggest that the Constitution prefers liberated religiosity. The Reconstruction Amendments, in contrast, are tough to read as promoting racial identity for its own sake or even for instrumental purposes. Antisorting would get more mileage out of a theory treating religion as constitutionally valued and religious divisions as indissoluble.

The conventional legal logic begins to stretch thin, but perhaps the nationalizing influence of the Civil War's resolution supports a neo-Madisonian theory of religious faction. Madison's now-hackneyed insight was that the collection of interests into a single political institution could facilitate reasoned compromise ${ }^{173}$ or at least prevent factional domination. He applied the theory to religious sects in The Federalist. ${ }^{174}$ But he did not touch state and local affairs. While Madison promoted federal constitutional guarantees of religious liberty against the states, he could not achieve it in the Bill of Rights. ${ }^{175}$ Yet the point is useful for an anti-sorting principle, because it sees religion as politically powerful rather than habitually subordinated. It recommends integrating multiple denominations within political institutions. And it limits the principle to groups dominating political jurisdictions, not simple geographic clumping. Christopher Eisgruber pushes similar arguments, singling out organized religion from other interests. Although critical to healthy societal diversity, he contends, religious groups are often cohesive, impervious to ordinary rational argument, and uncompromising because organized on matters of principle. ${ }^{176}$ These characteristics

${ }^{173}$ See Cass R. Sunstein, The Partial Constitution 19-20, 133-34, 347 (1993) (observing a general structural tendency in the Constitution to promote reasoned deliberation).

${ }^{174}$ See Federalist 10 in Clinton Rossiter, ed, The Federalist Papers 84 (1961) ("A religious sect may degenerate into a political faction in a part of the Confederacy; but the variety of sects dispersed over the entire face of it must secure the national councils against any danger from that source."); Federalist 51 at 324.

${ }^{175}$ Compare US Const, Amend I (singling out Congress), with Bernard Schwartz, The Great Rights of Mankind: A History of the American Bill of Rights 177, 233 (1977) (noting Madison's support for an amendment protecting "the equal rights of conscience" from state action).

${ }^{176}$ See Eisgruber, Madison at 372-73 (cited in note 13). 
might be accentuated when reinforced with a matching political boundary. Those lines can bolster group loyalty, and the use of government machinery may help solve any remaining collective action problems.

Such theories might leave little for a local government to decide, though. Before we take constitutional law to nationalize the primary school curriculum, it is worth recalling the virtues of decentralized democracy. Aside from the hoped-for benefits of Tiebout sorting, some democrats prefer a measure of decentralized government power because it creates locations for citizen participation. ${ }^{177}$ The wish is that people develop public-regarding arguments and interests, rather than simply presenting individual preferences for aggregation. ${ }^{178}$ In addition, interaction might produce cross-cultural knowledge and cooperation skills, which could themselves qualify as public goods. Other democrats are not interested in or oppose the goal of molding citizen interests through local politics, yet encourage decentralization for other reasons. Even representative forms of local government can be superior to wholly centralized power. Local officials might be better informed about local values and conditions, and local residents might be better informed about official conduct. If so, public policy can be more efficiently implemented and officials can be better monitored.

Neither theory for decentralized democracy is seriously assisted by religious homogeneity. This is clearer for participatory democrats. Many of them want citizens to confront and understand differences, not eliminate them by political boundaries or social pressure to conform. ${ }^{179}$ Representative democrats also have something to fear from religious sorting, even if preference homogeneity has upsides. One problem is group polarization. ${ }^{180}$ Given certain conditions, a group of individuals predisposed toward one position will end up supporting more extreme policies after deliberation than

\footnotetext{
${ }^{177}$ See, e.g., Frug, City Making at 20-24 (cited in note 110); Benjamin R. Barber, Strong Democracy: Participatory Politics for a New Age xiv-xv, 117 (1984).

${ }^{178}$ See Iris M. Young, Inclusion and Democracy 108-20, 188-89 (2000); Iris M. Young, 7ustice and the Politics of Difference 234-41 (1990); accord Diana L. Eck, A New Religious America: How a "Christian Country" Has Now Become the World's Most Religiously Diverse Nation 69-70 (2001).

${ }^{179}$ See, e.g., Young, fustice at 237-38 (cited in note 178); cf. Lee C. Bollinger, The Tolerant Society 9-10, 140-44 (1986) (justifying free speech as a method for developing tolerance).

${ }^{180}$ See, e.g., Cass R. Sunstein, Deliberative Trouble? Why Groups Go to Extremes, 110 Yale L J 71, 74-75 (2000).
} 
would have been predicted by their predeliberation preferences. In addition, too few dissenters can lead to no disagreement being voiced at all. And similar imbalances can generate cascades, as subsequent evaluations are skewed by prior political victories. ${ }^{181}$ Sometimes these syndromes might happily produce exciting social experiments. On other occasions the results might be disastrous, without a guarantee that the effects will be wholly localized or that participants will learn much from mistakes. Representative democracy might dampen the risks, but this seems less likely at the local level. As political boundaries encompass smaller populations, representatives and constituents begin to mirror a single social group. In this sense, secular enclaves are no different from their religious counterparts.

Lastly, social trends might make an anti-sorting norm attractive to many integrationists and nationalists. The country includes undeniably deep cultural divisions and religion plays a part. Few can believe that the United States will fit strong versions of the secularization thesis anytime soon, ${ }^{182}$ while empirical work suggests:

- co-religionists are clumped regionally and sometimes locally ${ }^{183}$-at the county level, perhaps to a degree now similar to segregation scores for African Americans; ${ }^{184}$

- foreign immigration trends may be contributing to religious separation, as newcomers sometimes bring shared religious commitments to geographically distinct communities; ${ }^{185}$

- fundamentalist denominations are gaining proportionally to

${ }^{181}$ See Cass R. Sunstein, Why Societies Need Dissent 5-13 (2003).

${ }^{182}$ The expectation, shared by intellectuals from Marx to Mill to Durkheim, was that modernity would diminish religiosity. See Jose Casanova, Public Religions in the Modern World 17-20, 211-12 (1994). Trends in some of Europe fit the thesis; but U.S. data are more difficult to square. See Pippa Norris and Ronald Inglehart, The Sacred and the Secular: Religion and Politics Worldwide 5, 84-85, 94 (2004); Laurence R. Iannoccone, Introduction to the Economics of Religion, $36 \mathrm{~J}$ Econ Lit 1465, 1468-72 (1998).

${ }^{183}$ See ARIS Survey at 39-42 (cited in note 22) (exhibit 15) (breaking down responses by state); Norris and Inglehart, The Sacred and the Secular at 94 (cited in note 182) (noting regional and urban/rural differences).

${ }^{184}$ See Rhode and Strumpf, 93 Am Econ Rev at 1670-71 (figures 5 and 6) (cited in note 110).

${ }^{185}$ See, e.g., Norris and Inglehart, The Sacred and the Secular at 93-94 (cited in note 182) (noting that proportional shifts away from "mainline" Protestant growth can be partly accounted for by immigration patterns); Rhode and Strumpf, 93 Am Econ Rev at 1672 (figure 7) (cited in note 110) (showing an increase in segregation by foreign birth, measured by Gini and dissimilarity indices, from 1960 to 1990). 
other sects; ${ }^{186}$

- yet the percentage of the population unaffiliated with any religious institution is substantial, if not growing. ${ }^{187}$

Religious segregation scores are worth pausing over. The calculations of Professors Rhode and Strumpf suggest that, between 1890 and 1990, the nation became equally segregated at the county level with respect to religions, African Americans, and the foreign born-with the first score falling slightly, the second falling substantially, and the third recently increasing. ${ }^{188} \mathrm{~A}$ single nationwide number for "religion" is not undoubtedly comparable to that for other social categories. The spatial distribution of many small sects must be aggregated to get a single segregation score, ${ }^{189}$ a handful of larger sects predominate in respective regions of the country, and our normative commitments are likely distinct in the religion context. But segregation indices are not the only relevant data point. With year 2000 county-level numbers, we can see that a single denominational family exceeds 50 percent of claimed adherents in a large number of counties. ${ }^{190}$ Although the percentage of residents who are claimed varies significantly across counties, the numbers may understate geographic unevenness in terms of anti-sorting con-

${ }^{186}$ See Finke and Stark, The Churching of America at 244-48 (cited in note 22); Norris and Inglehart, The Sacred and the Secular at 94 (cited in note 182); Iannoccone, 36 J Econ Lit at 1471-72 (cited in note 182).

${ }^{187}$ See ARIS Survey at $10 \&$ n 5, 13 (cited in note 22) (stating that in 2001, 14 percent responded "no religion" to the question "What is your religion, if any?" compared to 8 percent in 1990, when the question was "What is your religion?"); Norris and Inglehart, The Sacred and the Secular at 93 (figure 4.5) (cited in note 182) (showing a similar shift from 1991 to 2002 in responses to a General Social Survey question). Other polling indicates that about 94 percent of respondents will say they believe in some kind of god, however, with results fairly steady since 1947. See Norris and Inglehart, The Sacred and the Secular at 90 (table 4.1) (cited in note 182).

${ }^{188}$ See Rhode and Strumpf, $93 \mathrm{Am}$ Econ Rev at 1670-72 (figures 5-7) (cited in note 110) (showing scores from somewhat below 0.50 to about 0.60 ). Rhode and Strumpf's trendlines for "religion" in figure 6 are Gini and dissimilarity scores. Those scores are designed for a single group (see note 202) - not a single number for the 27 religion categories used by the authors. The formula they used to aggregate the scores is reproduced id at $1660-61$; it is a population-weighted average for each category, modified with a denominator that seems to further reduce the influence of small-group scores.

${ }^{189}$ Compare Alberto Alesina, Reza Baqir, and Caroline Hoxby, Political furisdictions in Heterogeneous Communities, $112 \mathrm{~J}$ Pol Econ 348, 361 (2004) (table 1) (showing an average county-level "heterogeneity" score of 0.631 for 17 Judeo-Christian groupings in 1990that is, there was a 63.1 percent probability that two randomly selected residents would not be members of the same grouping).

${ }^{190}$ See ASARB Data (cited in note 81 ) (fold-out map) (grouping all Baptists and Lutherans). 
cerns. A county that is relatively "diverse" as a whole might be divided at a more local level. Cook County, Illinois, to take a fairly extreme example, includes over 100 cities, villages, and towns, not to mention dozens more special purpose districts for education, parks, libraries, and so on. Strong anti-sorters might care about each of these divisions.

As discussed below, some of these trends are untroubling or even thrilling. Anti-sorting is not anti-diversity; indeed, it could be quite the opposite. The principle is concerned with how social divisions are institutionalized. When multiple social cleavages are piled upon each other, and then reinforced by coinciding political boundaries, there is cause to fear an overly fractionated country operating more as a confederation of monolithic associations than a nation of people sharing any fundamental commitment.

Likewise, it should be clear that anti-sorting principles are not anti-religion in a strong sense. Dispersing fellow believers is not the objective; the worry is alignment of religious and political borders. A denomination's geographic concentration is not problematic under the theory unless, for example, it falls within and dominates a single political jurisdiction. Furthermore, religious clumping within a political jurisdiction is not facially problematic if the jurisdiction as a whole is religiously diverse. ${ }^{191}$ The theory is concerned with monolithic local democracies, not neighborhoods lacking governmental authority. ${ }^{192}$ Second, the principle does not entail opposition to religion in politics. One can object to the coincidence of government institutions and uniform beliefs about religion without fearing the effects of religiosity on politics. ${ }^{193}$ In fact, antisorting is compatible with support for religious argument within democratic institutions. Yet it does imply qualms about organized

${ }^{191}$ What constitutes acceptable or optimal religious diversity is an enormous question for anti-sorting proponents. See note 202; Part III.C.

${ }^{192}$ Insofar as a "neighborhood" is a unit of local government under relevant law, antisorting theories apply with similar force. As for families, presumably they would be distinguished on the same public/private line that differentiates religions themselves, or by rights of intimate association and child-rearing. See, e.g., Roberts v United States faycees, 468 US 609, 618-19 (1984); Pierce v Society of Sisters, 268 US 510 (1925).

${ }^{193}$ Accord McDaniel v Paty, 435 US 618 (1978) (invalidating a ministerial exception). Contrast, for example, Vincent Blasi, Vouchers and Steering, 18 J L \& Pol 607, 613 (2002) ("[R]eligion remains a distinctively dangerous political force."), Abner S. Greene, The Political Balance of the Religion Clauses, 102 Yale L J 1611, 1614 (1993), and Kathleen M. Sullivan, Religion and Liberal Democracy, 59 U Chi L Rev 195, 197 (1992). 
religious factions, which ought to be accounted for by institutional choice and design.

A preference for mixing cannot achieve universal support, of course. Religious separatists dedicated to avoiding communities of sin, secularists convinced that religion is an infectious fraud, and still others will not be satisfied. Anti-sorting principles cannot be any more neutral than, say, basic commitments to liberal democracy. ${ }^{194}$ But unmitigated tolerance seems inconceivable for a functioning nation, and anti-sorting is consistent with a liberal goal of relative inclusion.

\section{B. APPLICATIONS}

If an anti-sorting principle is rightly planted in constitutional law, what form should it take in live controversies? Facets of the question track the debates about segregation by race. ${ }^{195}$ Should the Constitution be invoked only to prevent or remedy de jure state action that separates people or encourages them to separate among political subdivisions, or also to more affirmatively strive for integration as a matter of social fact? Or is religion-blindness the appropriate norm, such that conscious official efforts to integrate are forbidden by the Constitution? Before presenting a critique of anti-sorting principles, this section explores the options. It demonstrates that the idea, however controversial, can do lots of work.

1. Versions. Because the concern is political boundaries aligning with religious divisions, and assuming state and local governments retain significant authority and that their political community is importantly defined by physical territory, then there are two targets for anti-sorting principles: (1) the geographic distribution of people and (2) the physical location of political borders. Antisorting principles might affect either one, but parts of both targets are practically immobile. First, people have already sorted themselves to some degree and, although the U.S. population is fairly transient today, not everyone is interested in a change of scenery. Second, changing political boundaries is disruptive, administra-

\footnotetext{
${ }^{194}$ See John Rawls, Political Liberalism 199-200 (1996) (discussing education requirements).

${ }^{195}$ See generally David A. Strauss, Discriminatory Intent and the Taming of Brown, $56 \mathrm{U}$ Chi L Rev 935, 949 (1989); Greene, 96 Colum L Rev at 28-29 (cited in note 13) (analogizing racial segregation).
} 
tively and conceptually. It is theoretically possible intermittently to redraw municipal boundaries, as we do legislative districts, and local government lines already change through state-law mechanisms of incorporation and annexation. But the Constitution's text addresses boundary adjustments to one state that involve the territory of another state; ${ }^{196}$ almost any boundary change is costly as people adjust to a new polity and territorial unit; and some boundaries are so conceptually hardened that they are not going anywhere in the near term.

In the same spirit, certain extreme anti-sorting norms can be ruled out. The Constitution will not be read to mandate, and no court will order, the forced relocation of people to achieve an equal distribution by religion across municipalities. Compelled displacement for reasons related to religion is a liberty and property intrusion conceivable for settlers in Gaza but not for residents of the United States today; and equal distribution, even with an adequate measure, is just a bad idea in no way dictated by constitutional logic. Geographic quotas for every religious denomination and secular theory would be almost impossible to administer and normatively wrongheaded. Harmless or innovative sects with small memberships might not survive as their numbers are spread thin throughout a state or the nation. This is particularly true in the United States, where there are almost countless religions, from Druid to nondenominational Christian to Foursquare Gospel. ${ }^{197}$ And there is good reason to accept diverse versions of diverse localities. ${ }^{198}$

But anti-sorting law can be equally uncontroversial. At a minimum, subnational political boundaries could not be drawn by government officials to separate religious sects and/or the nonreligious against their will. The same can be said for coercive relocation of people to maintain separation across political boundaries. Both would be pure forms of mandatory segregation. They produce the threats associated with religious sorting without cap-

\footnotetext{
${ }^{196}$ See US Const, Art IV, $\$ 3$, cl 1 ("[Not] any State [shall] be formed by . . . Parts of States, without the Consent of the Legislatures of the States concerned as well as of the Congress."); cf. United States $v$ Louisiana, 363 US 1, 35 (1960) (indicating congressional control over state boundaries, at least at the point of admission to the Union).

${ }^{197}$ See ARIS Survey at 10, 12-13 (cited in note 22) (relying on self-identification).

${ }^{198}$ See Part III.C.
} 
turing the upside of unregulated private choice. ${ }^{199}$ Neither Karst nor Tiebout would be pleased. We might imagine two or more groups intensely opposed to each other's religious values, verging on violence and seeking each other's elimination, yet committed to ongoing confrontation within the same local political institution. At that point, government might produce adequately compelling reasons for separation. Otherwise, it is safe to assume that a plausible anti-sorting principle bars government officials from either drawing political boundaries or moving people to ensure religious segregation against (or regardless of) private party wishes. At the least, the principle reaches officials pusbing people apart on religious criteria without compelling reason.

The short logical extension is to state action beyond forced relocation or strategic boundary drawing, but which serves the same function. A useful analogy is to certain race-based equal protection claims under the Fourteenth Amendment. For facially race-neutral state action, the generic test requires more than disparate impact on a minority group; it demands discriminatory purpose..$^{200}$ For religion at least, the issue is not only minority subordination but also other risks posed by homogeneity like group polarization, conformity, cascades, and the threat to nonestablishment and free-exercise norms. So the ideas of disparate impact and discrimination can be supplemented with a concern for religious separation per se, as long as it takes place across political boundaries. A fairly minimal anti-sorting principle could therefore prohibit government action that is both (1) done for the purpose $^{201}$ of achieving religious homogeneity ${ }^{202}$ within a political

${ }^{199}$ See Board of Educ. of Kiryas 7oel Vill. Sch. Dist. v Grumet, 512 US 687, 690 (1994) (invalidating special legislation creating a school district at the request of a religious sect); cf. Gomillian v Lightfoot, 364 US 339, 341 (1960) (refusing to dismiss a challenge to new municipal boundaries that excluded almost all African-American voters who were part of the old jurisdiction).

${ }^{200}$ See Village of Arlington Heights $v$ Metropolitan Housing Dev. Corp., 429 US 252, 265 (1977).

${ }^{201}$ A satisfying test for official purpose is hard to find, particularly as applied to collectives. But we are not limited to direct inquiries into historical fact. Purpose can be checked by post hoc justifications and their fit with observable state action. See Republican Party of Minn. v White, 536 US 765, 779-80 (2002); Greater New Orleans Broad. Ass'n, Inc. v United States, 527 US 173, 187 (1999) (distinguishing asserted government interests from enacted legislative policy).

${ }^{202}$ This is a key clause for anti-sorting proponents to define and I do not offer a precise formula here. An indisputable example is a plan to achieve 100 percent adherence to a single church by 100 percent of the polity. But dangers of sorting will arise before then. Republic, Missouri's, vision of a Christian city seems sufficiently exclusionary, for example. 
jurisdiction $^{203}$ and (2) does or is likely to either (a) cause greater religious homogeneity within that jurisdiction or $(b)$ prevent reduction of such homogeneity—at least without a compelling justification.

This kind of "hold harmless" orientation is inelegant yet relatively manageable. It resists all calculated state action that risks pushing people in the direction of religious homogeneity. Once a court detects a purpose incompatible with any anti-sorting principle-achieving a religiously uniform citizenry through sortingthen the challenged state action cannot be carried out if it threatens to move the population toward that goal. Furthermore, a variety of conduct could violate the rule. It is not restricted to the construction of political boundaries or the physical relocation of people. On the other hand, the test does not make courts responsible for halting privately instigated religious sorting. It demands problematic government objectives, it is keyed to officials promoting a religious demography potentially at odds with disaggregated private choice, and it concentrates on homogeneity within a polity rather than trying to pick a version of "adequate religious diversity." ${ }^{204}$ Assuming a homogenous status quo, then, the town of Liberal, Missouri, could not use government resources to provide free land or down payments on houses for atheists alone.

In this vein, it is worth noting the many statistical measures of "segregation." See Douglas S. Massey and Nancy A. Denton, The Dimensions of Residential Segregation, 67 Social Forces 281, 282-83 (1988) (grouping 20 indices into categories of evenness, exposure, concentration, centralization, and clustering). "Evenness" is a candidate for anti-sorting purposes; it measures distribution of a given group's population across geographic subunits. See id at 283-84, 308 (recommending the dissimilarity index). Roughly speaking, the dissimilarity index is the proportion of a particular subpopulation that would have to move from their current subunit(s) to other(s) in order for each subunit to have the same percentage of that subpopulation. See Douglas S. Massey and Nancy A. Denton, American Apartheid: Segregation and the Making of the Underclass 20 (1993); Karl E. Taeuber and Alma F. Taeuber, Negroes in Cities: Residential Segregation and Neigbborbood Change 203-04 (1965). Evenness is not a very good measure of political power, however. A faith can be perfectly spread throughout all subunits and be a powerless minority, an ineffectual majority, or a commanding monolith in every one.

${ }^{203}$ The suggested test would not look for system-wide effects from state-encouraged sorting. This limit is intended as a sacrifice of ideal form in return for a test courts can more easily operate.

${ }^{204}$ Compare Samuel Issacharoff, Gerrymandering and Political Cartels, 116 Harv L Rev 593,627 (2002) (distinguishing the optimal number of firms in a competitive market from the identification of anticompetitive behavior); Richard H. Pildes, $A$ Theory of Political Competition, 85 Va L Rev 1605, 1612 (1999) ("In theory and in doctrine, we can often identify what is troublingly unfair, unequal, or wrong without a precise standard of what is optimally fair, equal, or right."). 
Nor could Republic, Missouri, do the same for members of the Southern Baptist Convention.

Another type of state action is not so purposeful or assertive yet it facilitates religious sorting. Illustrations are facially neutral procedures for incorporating new municipalities and state efforts to make publicly available accurate demographic data, including religious affiliation. Such action might be taken without any purpose that sorting will be increased or maintained. At this point, committed integrationists and Tiebout enthusiasts begin rapidly to diverge. The former will remain dedicated to preventing separation, regardless of official motives. As an analogy, some state action has been condemned for encouraging or facilitating racism or racial separation. The classic example is Shelley $v$ Kraemer. ${ }^{205}$ Case law under the Fair Housing Act might be an even better model, since it directly regulates communication. ${ }^{206}$ Some courts bar real estate advertisers from consciously picturing people of only one race, ${ }^{207}$ or real estate agents from supplying information on racial demographics. ${ }^{208}$ Such propositions could be exported to the religion context - the Act probably should be read to treat race and religion similarly, anyway-and then enforced as constitutional law against state action not expressly speaking to real estate transactions. ${ }^{209}$ Under this version of the anti-sorting principle,

${ }^{205} 334$ US 1 (1948); cf. Norwood v Harrison, 413 US 455, 466-67 (1973) (involving state aid to segregated schools); Reitman $v$ Mulkey, 387 US 369, 381 (1967) (involving an attempt to entrench the absence of antidiscrimination laws).

${ }^{206} 42$ USC $\$ 3604(\mathrm{c})$ (making it unlawful to "publish . . . any notice, statement, or advertisement, with respect to the sale or rental of a dwelling that indicates any preference, limitation, or discrimination based on race, color, religion, sex, handicap, familial status, or national origin").

${ }^{207}$ See Ragin v New York Times Co., 923 F2d 995, 1001-02 (2nd Cir) (affirming the denial of a publisher's motion to dismiss), cert denied, 502 US 821 (1991).

${ }^{208}$ See 42 USC $\$ 3604(a)$, (b), \& (d); 24 CFR $\$ 100.70$. There is disagreement over what constitutes unlawful "steering," however. Compare Village of Bellwood v Dwivedi, 895 F2d 1521, 1530-31 (7th Cir 1990) (demanding disparate treatment of customers because of race to make out a racial steering claim, such that accurately responding to customer requests about racial demographics apparently would not violate the Act) and Leadership Council for Metro. Open Communities, Inc. $v$ Rossi Realty, Inc., No 98 C 7852, 2001 WL 289870, at *5 (ND Ill 2001) (unpublished) (granting summary judgment for defendants on a religious-steering claim under the rule of Dwivedi), with Heights Community Congress $v$ Hilltop Realty Inc., 774 F2d 135, 140 (6th Cir 1985) (condemning conduct with the intent and effect of "steering," and suggesting that the Act can be violated by "truthful informational statements with racial content" or "failure to show homes in a particular location absent a specific request"), cert denied, 475 US 1019 (1986).

${ }^{209}$ There is no strong reason to think that rules first authored or suggested by Congress are unavailable for use by courts as constitutional law. In some instances Congress might 
and without an anti-subordination override of some variety, creating the Village of Kiryas Joel was constitutionally forbidden. Similarly, Congress's refusal to admit the Mormon-designed State of Deseret in the mid- $1800 \mathrm{~s}^{210}$ was constitutionally compelled. This certainly would be an aggressive constitutional rule. But recall that some Establishment Clause precedent, including the endorsement test, polices both government purpose and effect.

A difficult issue is then the official promotion of a jurisdiction as a haven for a particular denomination. This conduct might be painted as either an improper government effort to shape demographics or a justifiable provision of accurate information. Strong integrationists cannot accept such facilitation of sorting but Tiebout followers certainly might. Promotion of community character could be a municipal service that the model suggests people should sort over-a public good hindered by collective action problems, at least in localities filled with unorganized secularists or nondenominational Christians. For some uses of religious messages, the disagreement can be overcome. An official purpose to alter religious sorting patterns in a particular direction without residents' consent seems problematic, and officials might select crude or otherwise misleading messages for just that reason. ${ }^{211}$ Moving constitutional law much further, however, depends on a choice between fundamental commitments.

Some of these outcomes might be implausible, but there are even bolder strokes to be considered. One is whether governments may or must take affirmative action to create or maintain some kind of religious diversity - through promotional efforts or otherwise. ${ }^{212}$ Similar issues have been difficult to settle in the race context, and Justice Kennedy has suggested that the government has

be the first institution to articulate a rule that comports with a sound elaboration of the Constitution, but that does not mean that those rules cannot be mimicked or built on in court doctrine.

${ }^{210}$ See Dale L. Morgan, The State of Deseret 2-3, 9 (1987).

${ }^{211}$ But cf. Meese v Keene, 481 US 465, 467-69, 478-85 (1987) (rejecting a Speech Clause challenge to the federal government labeling certain foreign films "political propaganda," at least without evidence that the public was actually influenced or misled).

${ }^{212}$ Compare Kenneth T. Jackson, Crabgrass Frontier: The Suburbanization of the United States 138-55 (1985) (describing a trend roughly opposite: the rise of incorporation for suburban municipalities and the decline of annexation and consolidation for many large, older, central cities); Ankur J. Goel, Maintaining Integration Against Minority Interests: An Anti-Subjugation Theory for Equality in Housing, 22 Urban Law 369 (1990) (critically reviewing racial integration-maintenance measures, including ceiling quotas on minorities, steering, and equity insurance). 
a constitutional obligation to be religion-blind when choosing political boundaries. In his Kiryas foel concurrence he flatly stated, "government may not use religion as a criterion to draw political or electoral lines," 213 although he also referenced religious segregation as the problem at hand. ${ }^{214}$ But if the constitutional objective is preventing the social fact of religious segregation, then "diversity" efforts should be either presumptively valid or constitutionally mandated. This ambitious goal might not otherwise be achieved.

2. Implications. Legislative and executive action are not the only government influences on religious sorting. Court decisions also can play a role. An anti-sorting principle should prompt judiciaries to think about the consequences of their constitutional decisions for religious clumping across political boundaries. This might not entail massive doctrinal revision, but it would slant judicial choices in at least three ways.

First, a premium would be placed on uniformity in the treatment of religion by government across jurisdictions, to avoid incentives to sort. It follows that national decision making on issues of religious freedom would be preferred to local decision making. The former increases the likelihood that many religious and secular values are incorporated into the process for generating a national rule. ${ }^{215}$ In fact, this preference for centralized solutions is not a departure from current judicial practice. Last Term was an excellent illustration. At the same time the Justices divided over state and local Ten Commandments displays, they voted unanimously to reject an Establishment Clause challenge to a federal statute that required religious accommodations for prison inmates. ${ }^{216}$ The next most recent unanimous decision involving the Establishment Clause was nearly twenty years ago-and it likewise upheld a federal legislative accommodation. ${ }^{217}$

${ }^{213}$ Board of Educ. of Kiryas Foel Vill. Sch. Dist. v Grumet, 512 US 687, 728 (1994) (Kennedy, $\mathrm{J}$, concurring).

${ }^{214}$ See id; cf. United States v Hays, 515 US 737, 739, 744-46 (1995) ("We have never held that the racial composition of a particular voting district, without more, can violate the Constitution.").

${ }^{215}$ Not to say that the mix at the federal level is all-inclusive. Some sects may be without political leverage. This concern can be addressed, however, with a sect-neutrality principle. Accommodations for any religion or comparable secular interest would have to reach all "religions."

${ }^{216}$ See Cutter v Wilkinson, 125 S Ct 2113, 2117-18 (2005).

${ }^{217}$ See Corporation of Presiding Bishop of Cburch of fesus Cbrist of Latter-Day Saints v Amos, 483 US $327,329-30$ (1987). 
On the other hand, invalidation of the Religious Freedom Restoration Act as applied to state and local action in City of Boerne $v$ Flores ${ }^{218}$ looks inconsistent with a strong anti-sorting principle. The Act provided a uniform standard for mandatory government accommodation of religion. ${ }^{219}$ The Court's preferred test set out in Employment Division v Smith, ${ }^{220}$ which nearly forecloses required accommodation, ${ }^{221}$ might appear equally uniform. But the upshot of Smith empowered state politics to grant or withhold dispensations from secular burdens. ${ }^{222}$ Likewise is Locke $v$ Davey, ${ }^{223}$ which permitted the State of Washington to exclude devotional theology majors from a college scholarship program. Each of these decisions would be suspect at best. They open the possibility of substantial policy diversity across jurisdictions on the sensitive issue of religious accommodations, and therefore create incentives for religious sorting. It is possible, of course, that every jurisdiction will provide the same set of accommodations as they compete for religious residents. But this is quite improbable given variable local preferences. In this regard, the tension between the Court's pre-Smith Free Exercise and Establishment Clause decisions on religious exemptions ${ }^{224}$ no longer seems so bad. No one wants doctrine that simultaneously requires and forbids the same religious exemption. But narrowing the area of political discretion over exemptions should diminish incentives to sort. ${ }^{225}$

Second, a strong anti-sorting principle has a substantive bias beyond uniformity. More specifically, a liberty-based conception of religious freedom might be preferred to equality-based notions. The former is sensitive to government-imposed burdens on religion regardless of how the state treats anyone else. Outcomes do not nec-

\footnotetext{
${ }^{218} 521$ US 507 (1997).

${ }^{219} 42$ USC $\$ 2000$ bb-1(a)-(b) (prohibiting government from substantially burdening religious exercise unless it demonstrates that the burden serves a compelling governmental interest by the least restrictive means).

${ }^{220} 494$ US 872 (1990).

${ }^{221}$ See id at 879; Adam M. Samaha, Litigant Sensitivity in First Amendment Law, $98 \mathrm{Nw}$ U L Rev 1291, 1336-37 n 238 (2004) (listing Smith's possible limits).

${ }^{222}$ See Smith, 494 US at 890.

${ }^{223} 540$ US 712 (2004).

${ }^{224}$ See, e.g., Suzanna Sherry, Lee v Weisman: Paradox Redux, 1992 Supreme Court Review 123.

${ }^{225}$ Perhaps Congress rather than the Supreme Court should be setting national rules for religious exemptions. But an anti-sorting theory probably has little to say about that institutional choice.
} 
essarily depend on whether religion is being singled out, or whether a comparable group is receiving favorable treatment. An equalitybased conception is pegged to just such facts. This means that successful claims are contingent on the features of a particular legal regime. That is unfortunate from the anti-sorting perspective. Variance should be minimized, even if it cannot be eliminated over a series of applications.

Thus the outcomes might be the same in cases like Church of the Lukumi Babalu Aye $v$ City of Hialeab ${ }^{226}$-striking down local ordinances that singled out certain types of religiously motivated animal sacrifice $^{227}$ - and Tenafly Eruv Association v Borough of Tenafly ${ }^{228}$ holding that a municipality likely violated the Free Exercise Clause by prohibiting use of utility poles to demarcate an eruv. ${ }^{229}$ But the rationales would be rewritten to stress the burden on religious practice from the challenged regulation, instead of intentionally disparate government treatment compared to some other conduct. A similar objection might be lodged against some federal statutes. Legislation akin to the Equal Access Act of $1984^{230}$ might become problematic, although that particular statute's broad base of protected activities does relieve sorting fears, and the central source of decision making should be comforting.

Third, an anti-sorting orientation might define "religion." This is a notoriously difficult issue, ${ }^{231}$ but guidance is provided by the objective. The problem with which anti-sorting is concerned involves uniformity of values or worldview. This is the condition that arguably produces threats of group polarization, monitoring difficulties, risks of government-facilitated proselytizing or ostracism. Accordingly, the anti-sorting principle suggests definitions of religion focusing on a shared belief system about good and evil, the purpose and origins of life, the relationship of human beings to a

\footnotetext{
${ }^{226} 508$ US 520 (1993).

${ }^{227}$ See id at 524.

228309 F3d 144 (3d Cir 2002), cert denied, 539 US 942 (2003).

${ }^{229}$ See id at 167-68 (relying on lack of executive enforcement against similar conduct).

${ }^{230} 20$ USC $\$ 4071$ (a)-(b) (prohibiting public secondary schools that receive federal funding and that choose to create a "limited open forum" from denying student access to the forum on the basis of the "religious, political, philosophical, or other content of the speech at such meetings"); Board of Educ. of Westside Community Scbs v Mergens, 496 US 226, 253 (1990) (rejecting a facial challenge to the Act under the Establishment Clause).

${ }^{231}$ For helpful analysis, see Choper, Securing Religious Liberty at 64-86 (cited in note 60); Laurence H. Tribe, American Constitutional Law \$14-6 (2d ed 1988); and Kent Greenawalt, Religion as a Concept in Constitutional Law, 72 Cal L Rev 753 (1984).
} 
higher power, and so forth. For anti-sorting claims, the concept of religion would come close to Paul Tillich's description of "ultimate concern"232 and "deeply held" belief systems that guide human conduct, which were the target of Vietnam era conscientious objector cases. ${ }^{233}$ Second, an organization and an interactive community also seem relevant-the types of features stressed by Wisconsin $v$ Yoder, ${ }^{234}$ albeit in a case of near-complete exit. But longevity, rituals, belief in a personified god or gods, and written scripture would be far less important in and of themselves. This time, a broad belieforiented concept of religion would not be used to liberate individuals from secular power, but the concept nevertheless fits the aspirations of anti-sorting.

\section{RESERVATIONS}

Having pushed the anti-sorting idea about as far as it might go, we should conclude with some hardheaded skepticism. The last implication regarding the definition of religion is a useful starting point. It suggests monumental difficulties with strong versions of an anti-sorting principle, at least when enforced by courts as constitutional law. Once elaborated, the principle becomes hard to confine to "religion"; and if it is so confined, the principle will disadvantage co-religionists seeking political power through sorting. More concretely, if shared ideology is basically what makes religious homogeneity within political communities problematic, then conventional definitions of religion do not capture the threat. They are underinclusive. Geographic separation by partisan affiliation, for example, could produce the same dynamic. ${ }^{235}$ We might distinguish religious groups by their average commitment, cohesion, and unwillingness to compromise. ${ }^{236}$ But surely that characterization is a crude one. Conventional notions of religion are

${ }^{232}$ Paul Tillich, Dynamics of Faith 1-12 (1957).

${ }^{233}$ Welsh v United States, 398 US 333, 344 (1970) (exempting "those whose consciences, spurred by deeply held moral, ethical, or religious beliefs, would give them no rest or peace"); id at 344-45 (Harlan, J, concurring); see United States v Seeger, 380 US 163, 180-83 (1965).

${ }^{234} 406$ US 205, 216 (1972) (distinguishing the Amish and their "deep religious conviction, shared by an organized group, and intimately related to daily living").

${ }^{235}$ Compare Vietb v fubelierer, 124 S Ct 1769, 1799 (2004) (Kennedy, J, concurring) (refusing, at least for the time being, to impose federal constitutional restraints on partisan gerrymandering).

${ }^{236}$ See note 176 and accompanying text. 
also overinclusive for anti-sorting purposes. It is not clear that a monolithic community of, for example, nondenominational Christians presents the same risks of group polarization, lack of dissent, cascades, government proselytizing, and so on.

A lawyer's response-that religion must be treated differently because of constitutional text-is probably unavailable. It is not as if judicial suspicion of local action regarding religion was ever firmly guided by textualism. The judiciary certainly could have done a better job defending its application of non-establishment norms through the Fourteenth Amendment. Anyway, to be logically satisfying, anti-sorting principles might have to expand beyond religious separation, unless religion can be meaningfully distinguished in this context from other group characteristics. An argument, grounded in empirical fact, is needed to contrast religion from partisanship, race, gender, age, class, national origin, sexual orientation, and other concepts on which individuals might sort themselves. We can start by emphasizing shared values and organization, but that is just a beginning.

If religion is special, there are other powerful objections to strong anti-sorting principles. Normative complaints have been touched on above. We should not want a perfect distribution of religious and secular affiliates, even if we could get it. Particularly for groups posing no law-enforcement concerns and habitually losing political battles, a separate local government might do them and society much good. ${ }^{237}$ Some social experiments require uniformity of purpose before they can be evaluated; and allowing them to play out reflects a healthy skepticism about perfection in mainstream culture. ${ }^{238}$ Better that not every state and municipality end up like the Federal Election Commission: balanced and feckless.

A price of religious integration, furthermore, can be minority humiliation and unwanted assimilation. ${ }^{239}$ At least sometimes, sep-

${ }^{237}$ Compare Heather K. Gerken, Second-Order Diversity, 118 Harv L Rev 1099 (2005) (drawing from scholarship in local government law and using juries and districting as examples); Ankur J. Goel et al., Comment, Black Neigbborboods Becoming Black Cities: Group Empowerment, Local Control, and the Implications of Being Darker Than Brown, 24 Harv CRCL L Rev 415 (1988) (describing efforts to secede and incorporate East Palo Alto and Mandela as separate municipalities, and defending such a strategy for disadvantaged racial minorities).

${ }^{238}$ Accord Greene, 96 Colum L Rev at 8 (cited in note 13).

${ }^{239}$ Compare Board of Educ. of Kiryas Joel Vill. Sch. Dist. v Grumet, 512 US 687, 692 
aration defuses enough social friction to make up for losses in empathy, learning, and the hope for intergroup cooperation. As well, religiosity seems to correlate with desperate conditions. Often religion thrives where people are at the brink of elimination. ${ }^{240}$ Breaking up co-religionists into separate local democracies could dissipate solidarity that is useful for overcoming existential challenges. Perhaps there is no constitutional right to associate within a preferred government institution; but threats to disadvantaged communities ought to check any impulse favoring ambitious versions of an anti-sorting principle. In addition, religion has the potential of softening other problematic social divisions, like race. There is a long history of racial homogeneity in many U.S. churches, ${ }^{241}$ but not all. ${ }^{242}$ And there is always the draw of Tiebout, aggregated private choice, and interlocal competition.

Speaking of "diversity" raises a conceptual problem for an ambitious principle. What does it mean for a local political community to be sufficiently diverse when there are hundreds of recognized religions? "One of each" is not possible in a nation so vast without killing off countless sects. ${ }^{243}$ The hard job, therefore, would be to articulate a minimum requirement for religious diversity within all or some types of local government. ${ }^{244}$ Which religious "minorities" are substitutes for others? Should the law prioritize mainline mixing with the least powerful denominations, following a kind of anti-subordination value? Should it prize integration of denominations most in need of reconciliation, on the theory that social contact diminishes animosity? There are answers to these questions but it is tough to find them in conventional

(1994) (recounting social troubles of disabled Satmar children in the existing public schools).

${ }^{240}$ See Norris and Inglehart, The Sacred and the Secular at 240-41 (cited in note 182).

${ }^{241}$ See Kevin D. Dougherty, How Monochromatic Is Church Membership? Racial-Etbnic Diversity in Religious Community, 64 Soc of Relig 65, 74 (2003) (scoring a sample of congregations with the entropy index and noting that 42.9 percent were 100 percent racially homogenous).

${ }^{242}$ See ARIS Survey at 35 (cited in note 22) (exhibit 13); Howard Elinson, The Implications of Pentecostal Religion for Intellectualism, Politics, and Race Relations, 70 Am J Soc 403, 406, 414-15 \& n 34 (1965); see also John Burdick, What Is the Color of the Holy Spirit? Pentecostalism and Black Identity in Brazil, 109 Latin Am Res Rev 109, 124 (1999).

${ }^{243}$ See also Michael Lewyn, Suburban Sprawl, Jewish Law, and Jewish Values, 13 Southeastern Envt'l L J 1, 23 (2004) (arguing that "sprawl is to some extent a Jewish issue").

${ }^{244}$ For an attempt to define a "racially balanced" public school, see Comfort $v$ Lynn Scb. Comm., 418 F3d 1, 6-9 \& n 4 (1st Cir 2005) (en banc) (describing and upholding a local policy regulating the interschool transfer of pupils). 
constitutional sources. It is far easier to identify religious homogeneity than to agree on the appropriate concept for diversity.

A softer cautionary note arises from uncertainty about the extent of religious sorting in America. Empirical data on religious segregation are less reliable and precise than is standard for other divisions like race and income. True, and as noted above, a trendline of intercounty segregation scores can be calculated for religion. ${ }^{245}$ On the other hand, county-level numbers are probably too general and there are weaknesses in the underlying data ${ }^{246} \mathrm{At}$ least we can say that religiously homogenous counties are reason for integrationist worries, understanding that numbers alone will not depict political influence.

A related uncertainty is more important. Assuming there are troubling levels of religious separation-and that current separation is not so entrenched as to be irremediable-we lack a firm understanding of the mechanisms for religious sorting. ${ }^{247}$ Why and how deeply do people prefer to stick with fellow believers in a state or municipal setting? It is not difficult to imagine that many people feel most comfortable, or are only comfortable, when their values and morality are reflected in those around them. This is true for denominations like the Old Order Amish and many Orthodox Jews. Yet we also know that people choose living, work, and recreational places for several reasons. Surveys indicate that residential location choices are often prompted by housing, family, or employment needs that are not necessarily related to religion. ${ }^{248}$

${ }^{245}$ See Rhode and Strumpf, 93 Am Econ Rev at 1671 (table 6) (cited in note 110).

${ }^{246}$ See note 82 and accompanying text.

${ }^{247}$ Compare Taeuber and Taeuber, Negroes in Cities at 28 (cited in note 202) (distinguishing processes from patterns of residential racial segregation). There are case studies from which lessons might be drawn. See Gerald Gamm, Urban Exodus: Why the Fews Left Boston and the Catholics Stayed 15-24 \& n 10 (1999) (claiming that Jewish and Protestant congregations tend to be less territory-oriented than Catholic parishes, at least before Vatican II).

${ }^{248}$ See U.S. Census Bureau, American Housing Survey for the United States (2003) (table 2-11) (displaying results of survey questions on reasons/the main reason for choosing present neighborhood; reporting significant numbers under "looks/design" and "other"); U.S. Census Bureau, Why People Move: Exploring the March 2000 Current Population Survey 2 (2001).

The relative paucity of data on religious sorting in the United States might reflect relative calm among religions and secularists. Contrast research in countries with recent histories of serious interfaith battles, like Israel and Northern Ireland. See, e.g., A. S. Adair et al., The Local Housing System in Craigavon, N. Ireland: Etbno-religious Residential Segregation, Socio-tenurial Polarisation and Sub-markets, 37 Urban Studies 1079 (2000); John McPeake, Religion and Residential Searcb Bebaviour in the Belfast Urban Area, 13 Housing 
Religious demographics might play a role within the set of choices bounded by other necessities; but there seems to be no good formula for now. Furthermore, there is reason to believe that race and income are, on the whole, more powerful drivers of jurisdictional separation. Unlike religious heterogeneity scores, racial and income heterogeneity recently have been connected to the number of municipalities within U.S. counties. ${ }^{249}$ On a related note, it is likely that some religious sorting is an artifact of other social divisions. Perhaps much religious separation is a consequence of racial separation. If so, attacking the former would not relieve sorting pressures generated by the latter.

Furthermore, it is not clear that tipping models for neighborhood changes in racial composition ${ }^{250}$ work the same way for religion. Again, religion is less visible than race; and it might well be that fewer Americans feel strongly about the addition of new religions to their localities. Perhaps this bodes well for integration efforts, but it also suggests that any preferences for religious homogeneity will often be overrun by other factors. To the extent that the urge to sort religiously remains salient, we cannot be certain of the degree to which state action is implicated. With respect to government signaling, sometimes messages about demographics and power can be credibly delivered by private parties. ${ }^{251}$ Organized religious groups have, by definition, overcome collective action problems. Uncertainty about the system of religious sorting in the United States today makes it hard to defend ambitious anti-sorting principles.

Studies 527 (1998); Itzhak Omer and Itzhak Benenson, Investigating Fine-Scale Residential Segregation, by Means of Local Spatial Statistics, 12 Geographical Res F 41 (2002).

${ }^{249}$ See Alesina et al, $112 \mathrm{~J}$ Pol Econ at 360-63, 387-91 (cited in note 189) (concentrating on 1960 and 1990, using 17 Judeo-Christian groupings, and calculating "heterogeneity" by the probability that two randomly selected residents will be members of the same group). The authors did, however, find a statistically significant relationship between the number of school attendance districts (in contrast to school districts) and religious heterogeneity at the county level, and which was stronger than that for such racial or income heterogeneity. See id at 368 (reporting that a two-standard-deviation increase in religious heterogeneity is associated with a 15 percent increase in school attendance areas).

${ }^{250}$ See generally Thomas C. Schelling, Micromotives and Macrobebavior 140-55 (1978); Abraham Bell and Gideon Parchomovsky, The Integration Game, 100 Colum L Rev 1965 (2000).

${ }^{251}$ After the Seventh Circuit barred a Ten Commandments monument from the lawn in front of the Elkhart municipal building, see Books $v$ City of Elkhart, 235 F3d 292, 295 (7th Cir 2000), cert denied, 532 US 1058 (2001), it was relocated to a plot owned by a lumber company along the Riverwalk, see Indiana Ten Commandments Case Won't Be Reopened, AP, Aug 15, 2002. 
These reservations do not mean that an anti-sorting principle is worthless or that courts should never intervene to prevent religious separation. Total judicial abstention and unyielding judicial enforcement of aggressive anti-sorting rules are equally extravagant positions. Yet current constitutional law has the advantage of flexibility; anti-sorting ideas are present but not fully articulated. We can therefore advocate small steps without disrupting settled law. Despite the uncertainties, courts have strong reason to enforce a rule along the lines of the one suggested above ${ }^{252}$-invalidating government action if it is both designed and likely to help achieve religious homogeneity within a political jurisdiction-at least absent a genuine purpose of accommodating a subordinated group in accord with free-exercise values. Furthermore, a modest antisorting principle should affect other constitutional doctrine drafted by courts. In situations of reasonable doubt, the judiciary should favor doctrine that is less likely to generate religious sorting across political boundaries. Even these cautious moves are subject to dispute, of course, for being too loose or too vague. But they are defensible guidelines for courts. Going much further would require knowledge and justification that we do not now have.

All of this indicates that the Supreme Court was correct to leave the Texas monument alone and perhaps wrong to order removal of the McCreary County display. Signaling a local religious character is within the concern of even modest anti-sorting principles. But those versions of the principle have little apprehension for a forty-year-old monument, sharing space with other sculpture on state capitol grounds, identified by date and private donor. It is hard to imagine this icon having much present effect on decisions of outsiders to locate or visit in Austin or the State of Texas, and the limited record provided no reason to believe that the politicians who accepted the gift intended otherwise. The anti-proselytism principle can complement anti-sorting arguments, but the former has little traction in this setting. McCreary County's promotional efforts are more troubling, but likely innocuous as a constitutional matter without additional information. Placing a Decalogue inside a building used for vehicle registration and trial court business is a poor strategy for attracting or repelling transients. A high-profile external display would be far more vulnerable

${ }^{252}$ See text accompanying notes 199-204. 
to anti-sorting arguments. ${ }^{253}$ This does not imply that anti-sorting principles will not invalidate state action that is likely to occurwhich might be an unhealthy requirement for constitutional doctrine in any event. Republic, Missouri, is not the only contemporary American polity that has indicated a longing to manufacture religious homogeneity. ${ }^{254}$

\section{Conclusions}

The endorsement test is, like the rest of the doctrine surrounding religious establishments, primarily concerned with state and local misbehavior. There are historical, structural, and theoretical reasons for this. But taking away majority-supported symbols generates more resentment than one might anticipate. So it makes sense to have a strong reason for doing it. Anti-proselytism-preventing state power from joining or overrunning religious missions to inculcate citizens-is a defensible constitutional objective. However, this problem is not strongly implicated by many public religious messages. And supporters of the anti-proselytism principle seem to take community membership as unrealistically static. Adding an anti-sorting principle-which would cover state and local governments influencing their demographics by the strategic deployment of religious symbols-provides needed heft to the non-endorsement idea. Equally important, the principle understands political community membership as dynamic and shaped by state action.

At the same time, humility is in order. We do not know all that we reasonably might about the system of religious sorting in America. In addition, strong anti-sorting rules are understandably controversial. Nobody should want an even distribution of every identifiable denomination and secular philosophy across every political jurisdiction. A defensible measure of "religious diversity," moreover, is not readily available. Nor will the work done on race smoothly carry over into the religion context, where the historical, sociological, and normative differences fall somewhere between

\footnotetext{
${ }^{253} \mathrm{It}$ is possible that a relatively poor area like McCreary meant to boost local loyalty to the County by reflecting community values as a way of retaining population. But without more evidence, this is speculation.

${ }^{254}$ See notes $89-95$ and accompanying text (collecting examples that might constitute unconstitutional government encouragement of religious sorting by political jurisdiction, all of which took place during the development of the endorsement test).
} 
significant and massive. Tempered measures are best, especially with respect to constitutional law enforced by courts. For now the judicial focus ought to be on religious homogeneity within political jurisdictions, official action that consciously and effectively promotes or entrenches such sorting, and the sorting risks that accompany other doctrinal choices. Doing this much would be relatively unambitious yet meaningful.

Whatever are the appropriate doctrinal implications, an antisorting perspective focuses on questions that matter. It pinpoints live social phenomena in a modern, dynamic, and religiously diverse nation. This should be a welcome addition to our continuing search for the proper relationship between religion and political institutions. If remixing the Supreme Court's composition helps us revisit this relationship, then the endorsement test's inevitable retirement is also a hopeful beginning. 
HeinOnline -- 2005 Sup. Ct. Rev. 1942005 